IZA DP No. 8093

Are Ghettos Good or Bad?

Evidence from U.S. Internal Migration

Junfu Zhang

Liang Zheng

April 2014 


\title{
Are Ghettos Good or Bad? Evidence from U.S. Internal Migration
}

\author{
Junfu Zhang \\ Clark University \\ and IZA \\ Liang Zheng \\ Central University of Finance and Economics
}

Discussion Paper No. 8093

April 2014

IZA
P.O. Box 7240
53072 Bonn
Germany

Phone: +49-228-3894-0

Fax: +49-228-3894-180

E-mail: iza@iza.org

Any opinions expressed here are those of the author(s) and not those of IZA. Research published in this series may include views on policy, but the institute itself takes no institutional policy positions. The IZA research network is committed to the IZA Guiding Principles of Research Integrity.

The Institute for the Study of Labor (IZA) in Bonn is a local and virtual international research center and a place of communication between science, politics and business. IZA is an independent nonprofit organization supported by Deutsche Post Foundation. The center is associated with the University of Bonn and offers a stimulating research environment through its international network, workshops and conferences, data service, project support, research visits and doctoral program. IZA engages in (i) original and internationally competitive research in all fields of labor economics, (ii) development of policy concepts, and (iii) dissemination of research results and concepts to the interested public.

IZA Discussion Papers often represent preliminary work and are circulated to encourage discussion. Citation of such a paper should account for its provisional character. A revised version may be available directly from the author. 
IZA Discussion Paper No. 8093

April 2014

\section{ABSTRACT}

\section{Are Ghettos Good or Bad? Evidence from U.S. Internal Migration*}

It is difficult to determine whether ghettos are good or bad, partly because racial segregation may have some effects that are unobservable. To overcome this challenge, we present a migration choice model that allows for estimating the overall effects of racial segregation. The key idea underlying our empirical approach is that if segregation indeed has a negative overall effect, migrants should be willing to give up some earnings to avoid living in segregated cities. Using decennial census data from 1980 to 2000, we provide new evidence that ghettos are bad. It is shown that both black and white migrants prefer to live in less segregated cities. For example, for a one-percentage-point reduction in the dissimilarity index, the estimated marginal willingness to pay of blacks is \$436 (in 1999 dollars) in 2000. Among whites, this marginal willingness to pay is $\$ 301$.

JEL Classification: O15, R12, R23

Keywords: residential segregation, internal migration, discrete choice model

Corresponding author:

Junfu Zhang

Department of Economics

Clark University

950 Main Street

Worcester, MA 01610

USA

E-mail: juzhang@clarku.edu

\footnotetext{
* This paper has benefited from comments by John Brown, Wayne Gray, Nathan Schiff, and conference participants at the 8th Meeting of the Urban Economics Association. All errors are our own.
} 


\section{Introduction}

Racial residential segregation is one of the most salient features of urban America. With the massive migration of blacks from rural South to urban North, racial segregation in American cities started in the early twentieth century, expanded substantially after the Second World War, and peaked in the 1970s (Cutler et al. 1999). Although segregation began to decline nationally beginning in the 1970s, steps toward widespread integration remain modest (Logan et al. 2004). By 2000, in the average U.S. city, 50 percent of blacks would have to be relocated in order for whites and blacks to be evenly distributed across neighborhoods. ${ }^{1}$

It has long been argued that the persistence of segregation is the root cause of the "black underclass" in American cities (Wilson 1987; Massey and Denton 1993). Numerous empirical studies find that segregation has adverse effects on a variety of social and labor market outcomes for blacks. ${ }^{2}$ The standard explanation for such negative effects is that living in highly segregated areas spatially separates blacks from job opportunities, reduces their access to high quality local public goods, and diminishes many of the positive spillovers from skilled whites via "neighborhood effects" (Kain 1968; Wilson 1987; Borjas 1995).

Existing studies of the effects of segregation have two features in common. First, each study focuses on one or few outcomes. For this reason, given all the negative effects of segregation identified in this literature, one may still hesitate to conclude that ghettos are indeed bad. ${ }^{3}$ There is always the possibility that some benefits of segregation, such as psychic and cultural satisfaction, are missed in these studies because they are difficult to measure. Second, the existing literature focuses primarily on the effects of segregation on minority groups (especially blacks) and pays much less attention to its effects on whites. The well being of whites, however, can certainly be affected by segregation. It is well known that segregational residential patterns do not necessarily reflect individual preferences (Schelling 1971; Zhang 2011). That is, even in highly segregated cities, there may be a large fraction of whites who actually prefer racial diversity. Since segregation allows for few racially diverse neighborhoods and schools, these whites may consider

\footnotetext{
${ }^{1}$ In this paper, the term "city" refers to a metropolitan statistical area (MSA) and the term "neighborhood" refers to a census tract.

${ }^{2}$ Many studies focus on the effects of residential segregation on employment outcomes of blacks (see, e.g., Kain 1968, Ellwood 1986, Kasarda 1989, Ihlanfeldt and Sjoquist 1990, and Weinberg 2000). Some others examine the effects on black educational achievement (e.g., Card and Rothstein 2007), crime rates (e.g., Shihadeh and Flynn 1996, Krivo et al. 2009), health status (e.g., Williams and Collins 2001), and poverty (e.g., Ananat 2011). Cutler and Glaeser (1997) is a more comprehensive study that estimates the effects of segregation on the outcomes of blacks along several dimensions, including educational achievement, income, employment, and the probability of becoming a single mother.

${ }^{3}$ Following Cutler and Glaeser (1997), we use the term "ghetto" to refer to a racially segregated community.
} 
segregation undesirable. Even for whites who favor predominantly white neighborhoods and schools, segregation may create disutility if they feel uncomfortable using public facilities in predominantly black neighborhoods and are essentially locked out of certain parts of the city. Therefore, any comprehensive welfare analysis must also take into account the effects of segregation on whites.

This paper contributes to the literature by estimating the overall effects of segregation on blacks as well as whites. The logic behind our empirical analysis is simple: In the context of internal migration, individuals choose the city where they derive the highest utilities. Cities are characterized by varying income opportunities and segregation levels. Holding everything else constant, migrants face a trade-off between the level of segregation and expected income when they choose a city to live in. If migrants are willing to give up some earnings in order to live in less segregated cities, then segregation must be bad; otherwise, if the opposite is true, segregation must be good.

Our empirical approach follows Bayer et al. (2009), who estimate a discrete choice model of internal migration decisions to measure the value of air quality in U.S. cities. Despite the narrow focus of their study, Bayer et al. (2009) provide a rather general method for quantifying revealed preferences for any urban amenities or disamenities at the city level. We apply this method to study migrants' willingness to pay for cities with different degrees of segregation. Our innovation is to treat residential segregation as an urban (dis)amenity, which represents a significant deviation from the existing literature on the effects of segregation.

Two related studies, Bayer et al. (2007) and Bajari and Kahn (2005), also estimate discrete-choice models to measure preferences toward racial residential segregation in U.S. cities. However, both papers examine within-city residential choices. Using data from the San Francisco Bay Area, Bayer et al. (2007) find that blacks are willing to pay for an increased share of black population in a census block group but whites are not, consistent with the notion that people prefer segregation at the block-group level. ${ }^{4}$ In contrast, using data from Atlanta, Chicago, and Dallas, Bajari and Kahn (2005) find that at the level of a much larger community (public use micro areas, or PUMAs), whites are willing to pay for integration and blacks prefer whiter communities, suggesting that people want to avoid segregation at the PUMA level. The discrepancy between these findings raises the question whether only segregation at higher geographic levels has adverse effects on individual outcomes. Our study helps answer this question by examining revealed preferences for segregation at the city level based on cross-city residential choices.

To provide a structural framework for empirical analysis, we present a model of mi-

\footnotetext{
${ }^{4}$ Following a similar approach to Bayer et al. (2007), Wong (2013) finds that in Singapore all ethnic groups prefer to live with some own-ethnic-group neighbors, but only up to certain levels. That is, people would like to have some but not complete segregation.
} 
gration destination choices in which the degree of segregation directly enters individual utilities. We follow a standard two-step procedure to estimate the model: At the first step, a discrete choice model is used to recover a vector of city-specific utilities that are common to all individuals living in these cities. At the second step, we regress these city-specific utilities on city level segregation, along with other city characteristics, to measure the marginal willingness to pay (MWTP) for segregation. A naive OLS estimate of this willingness to pay is likely to be biased if segregated cities have unobserved city characteristics that affect utilities. To address this issue, we instrument for city level segregation. We use two sets of instruments, both drawn from the existing literature: the structure of governmental finance (Cutler and Glaeser 1997) and the number of interand intra-county rivers (Hoxby 2000; Rothstein 2007).

Using decennial census data from 1980 to 2000, we find that utilities from segregation are aways negative and they are statistically significant for young blacks in 1990 and 2000 and for young whites in all three census years. The magnitudes of these disutilities are large and appear to vary across races and over time. For a one-percentage-point reduction in the dissimilarity index, our preferred estimates imply that the MWTP among blacks increases from $\$ 89$ to $\$ 436$ between 1980 and 2000 (in 1999 dollars). For whites, however, the MWTP decreases from $\$ 675$ to $\$ 301$ during this same period. In addition, we also find that, in some samples, MWTP falls with age and rises with the presence of children. In contrast, educational attainment has no significant effect on MWTP in all samples. Taken together, our estimates suggest that ghettos are bad for both young blacks and young whites. To the best of our knowledge, these findings represent the first set of estimates of people's willingness to pay to avoid racially segregated cities.

The remainder of the paper is organized as follows: Section 2 presents a simple migration choice model for empirical analysis. Section 3 describes the data and identification strategies. Section 4 presents empirical results. Finally a brief summary in Section 5 concludes this paper.

\section{A Migration Choice Model}

We start by modeling individual location choices among a set of $J$ cities. In any city $j$, an individual $i$ chooses the quantity of numeraire good $C_{i j}$ and housing $H_{i j}$ to maximize a city-specific Cobb-Douglas utility subject to the budget constraint:

$$
\begin{gathered}
\operatorname{Max} \quad U_{i j}=C_{i j}^{\beta_{c}} H_{i j}^{\beta_{h}} S_{j}^{\beta_{i s}} X_{j}^{\beta_{x}} e^{M_{i j}+\xi_{j}+\epsilon_{i j}} \\
\text { s.t. } \quad C_{i j}+p_{j} H_{i j}=W_{i j},
\end{gathered}
$$


where $S_{j}$ is the level of segregation in city $j ; X_{j}$ and $\xi_{j}$ are other observed and unobserved city characteristics in city $j$, respectively; $M_{i j}$ captures the psychic costs of moving from birth place to city $j$; and $\epsilon_{i j}$ represents the idiosyncratic component of utility, which is independent of city characteristics and migration costs. $W_{i j}$ is individual $i$ 's wage in city $j ; p_{j}$ is the price of housing in city $j$; and the price of $C_{i j}$ is normalized to 1 . Note that except for segregation, we assume homogeneous preferences and therefore $\beta_{c}, \beta_{h}$, and $\beta_{x}$ are not indexed by $i$. We allow the preference for segregation to vary across individuals, because it would be informative to know whether segregation has any differential effects on different groups of people. It is also worth noting that in our empirical analysis below, we will estimate the model separately for blacks and whites in different census years. That is, we allow all taste parameters to vary by race and cohort. To keep notation clean, however, we have suppressed race and year indexes here.

The utility maximization problem yields the following demand functions:

$$
C_{i j}^{*}=\frac{\beta_{c}}{\beta_{c}+\beta_{h}} W_{i j} \quad \text { and } \quad H_{i j}^{*}=\frac{\beta_{h}}{\beta_{c}+\beta_{h}} \frac{W_{i j}}{p_{j}}
$$

Plugging $C_{i j}^{*}$ and $H_{i j}^{*}$ into the utility function, letting $\beta_{w}=\beta_{c}+\beta_{h}$, and rescaling utility by $\left(\frac{\beta_{c}}{\beta_{c}+\beta_{h}}\right)^{-\beta_{c}}\left(\frac{\beta_{h}}{\beta_{c}+\beta_{h}}\right)^{-\beta_{h}}$, we obtain the indirect utility function

$$
V_{i j}=W_{i j}^{\beta_{w}} p_{j}^{-\beta_{h}} S_{j}^{\beta_{i s}} X_{j}^{\beta_{x}} e^{M_{i j}+\xi_{j}+\epsilon_{i j}} .
$$

For empirical analysis, the psychic migration cost $M_{i j}$ is specified as:

$$
M_{i j}=m_{1} d_{1 i j}+m_{2} d_{2 i j}+m_{3} d_{3 i j}
$$

where $d_{1 i j}$ is 1 if city $j$ is outside individual $i$ 's birth state and 0 otherwise; $d_{2 i j}$ is 1 if city $j$ is outside individual $i$ 's birth division and 0 otherwise; $d_{3 i j}$ is 1 if city $j$ is outside individual $i$ 's birth region and 0 otherwise. ${ }^{5}$

Since we can only observe each person's actual wage in his chosen city, we need to estimate how much they would earn in the cities they do not choose. Following Bayer et al. (2009) and Timmins (2007), we construct the following decomposition:

$$
\ln W_{i j}=\ln \hat{W}_{i j}+\nu_{i j}
$$

where $\ln W_{i j}$ is the logarithm of the actual wage that individual $i$ would earn in city $j$; $\ln \hat{W}_{i j}$ is the logarithm of individual $i$ 's estimated wage in city $j$; and $\nu_{i j}$ is an idiosyncratic error term. We will describe at length the method of obtaining $\ln \hat{W}_{i j}$ in the data section.

\footnotetext{
${ }^{5}$ There are nine U.S. census divisions (New England, Middle Atlantic, East North Central, West North Central, South Atlantic, East South Central, West South Central, Mountain, and Pacific) and four U.S. census regions (Northeast, Midwest, South, and West).
} 
To allow for heterogeneous preferences for segregation, we assume that $\beta_{i s}$ is a function of observed individual characteristics:

$$
\beta_{i s}=\beta_{s}+\sum_{c} \beta_{s c} z_{i c}
$$

where $z_{i c}$ is individual $i$ 's observed characteristic $c$ (e.g., educational attainment); $\beta_{s c}$ represents heterogeneous preferences for segregation that vary with $z_{i c}$. Each $z_{i c}$ is demeaned (i.e., subtracted by its sample average) so that $\beta_{s}$ represents the mean preference for segregation.

Substituting equations (4)-(6) into (3) and taking natural logs yield

$$
\ln V_{i j}=\Theta_{j}+\lambda_{i j}+\eta_{i j}
$$

where

$$
\begin{gathered}
\Theta_{j}=\beta_{s} \ln S_{j}+\beta_{x} \ln X_{j}-\beta_{h} \ln p_{j}+\xi_{j} \\
\lambda_{i j}=\beta_{w} \ln \hat{W}_{i j}+m_{1} d_{1 i j}+m_{2} d_{2 i j}+m_{3} d_{3 i j}+\sum_{c} \beta_{s c} z_{i c} \ln S_{j}
\end{gathered}
$$

and

$$
\eta_{i j}=\beta_{w} \nu_{i j}+\epsilon_{i j}
$$

In equation (7), $\Theta_{j}$ represents a city-specific constant that extracts the portion of utility provided by city $j$ that is common to all individuals. From this point on, we refer to it as city-specific mean utilities. $\lambda_{i j}$ captures the portion of utility provided by city $j$ that varies by individual wage, birth place, and observed individual characteristics. $\eta_{i j}$ is the error term that combines individual $i$ 's idiosyncratic preferences for city $j$.

To estimate the model parameters of interest, we follow a two-step estimation procedure developed by Berry (1994) and Berry et al. (1995). With the assumption that $\eta_{i j}$ is an independently and identically distributed type I extreme value, the probability that individual $i$ chooses city $j$ has the following standard logit form:

$$
P_{i j}\left(\ln V_{i j} \geq \ln V_{i k} \forall k \neq j\right)=\frac{\exp \left(\Theta_{j}+\lambda_{i j}\right)}{\sum_{s=1}^{J} \exp \left(\Theta_{s}+\lambda_{i s}\right)} .
$$

Given the assumption of independent individual decisions, the probability that each person in the sample makes the actually observed choice is

$$
L=\prod_{i} \prod_{j=1}^{J} P_{i j}^{\kappa_{i j}}
$$

where $\kappa_{i j}$ is 1 if city $j$ is chosen by individual $i$ and 0 otherwise. The first step of our 
estimation procedure is to maximize $L$ by searching over a vector of city-specific constants $\left(\Theta_{j}\right)$ and the parameters in $\lambda_{i j}$.

Since there is a large number of cities, we use a contraction mapping algorithm developed by Berry (1994) and Berry et al. (1995) to facilitate the estimation of city-specific constants $\left(\Theta_{j}\right)$. Let $s_{j}$ be the share of migrants in the sample who actually choose city $j$, and $\hat{s}_{j}\left(\Theta_{j}\right)=\frac{1}{N} \sum_{i=1}^{N} P_{i j}$ be the predicted share of individuals who choose city $j$, where $N$ is the total number of individuals. The maximum likelihood estimation with contraction mapping proceeds as follows: (1) Starting with any trial value of parameters in $\lambda_{i j}$, the city-specific constants are obtained by iteratively adjusting the formula: $\Theta_{j}^{t+1}=\Theta_{j}^{t}+\ln s_{j}-\ln \hat{s}_{j}\left(\Theta_{j}^{t}\right)$, where $t$ indexes the iterations. ${ }^{6}$ (2) Plug the estimated city-specific constants into the likelihood function and use a gradient-based method to generate new estimated parameters in $\lambda_{i j}$, which will be used as the new trial value. (3) Repeat (1) and (2) until the likelihood function is maximized.

Once the estimates of $\Theta_{j}$ are obtained, the second step of the procedure is to estimate the mean preference for segregation $\left(\beta_{s}\right)$ via a simple linear equation (8). However, a naive OLS estimate of $\beta_{s}$ may be biased due to potential endogeneity issues. First, it is very likely that any improvement in unobserved city amenities in $\xi_{j}$ will lead to an increase in housing price $\left(p_{j}\right)$. Regardless of whether the estimate of $\beta_{h}$ is biased, the endogeneity of housing price itself may spill over to the estimate of $\beta_{s}$. To cope with this issue, following Bayer et al. (2009), we rewrite equation (8) by moving $\beta_{h} \ln p_{j}$ to the left-hand side:

$$
\Theta_{j}+\beta_{h} \ln p_{j}=\beta_{s} \ln S_{j}+\beta_{x} \ln X_{j}+\xi_{j}
$$

where the new dependent variable $\left(\Theta_{j}+\beta_{h} \ln p_{j}\right)$ can be thought of as "housing-priceadjusted city-specific mean utilities." 7 Notice that from equation (2) $\beta_{h}=\beta_{w} \frac{H_{i j}^{*} p_{j}}{W_{i j}}$, where $\beta_{w}$ is the marginal utility of wage and can be obtained from the first step of the estimation procedure; $\frac{H_{i j}^{*} p_{j}}{W_{i j}}$ is the share of income spent on housing which can be estimated from data.

The second concern is that more racially segregated cities may have unobserved city amenities and disamenities in $\xi_{j}$ that affect individual utility. For example, cities with ghettos may have better ethnic restaurants and a unique culture; such cities may also suffer from a declining industrial base and be ill equipped to provide a variety of local public goods. To address this source of potential bias, we take the standard instrumental

\footnotetext{
${ }^{6}$ Berry (1994) shows that, for any given parameters in $\lambda_{i j}$, there exists a unique set of $\Theta_{j}$ that equates the predicted with the actual shares. Berry et al. (1995) further prove that the adjustment process is a contraction mapping and will converge to the exact solution.

${ }^{7}$ An alternative approach to dealing with the endogeneity of housing price is to find valid instrumental variables for housing price. For example, to instrument for the price of a given house, Bayer et al. (2007) use the exogenous attributes of houses and neighborhoods that are located a certain distance away. Ferreira (2010) uses the variation from transaction costs generated by California's Proposition 13 property tax law. Wong (2013) exploits a unique ethnic housing quota policy implemented in Singapore.
} 
variables approach. Specifically, we use two sets of instruments for segregation-both drawn from the existing literature - that exploit variations in segregation caused by fiscal factors and topographic features.

\section{Data and Identification}

In this section, we briefly describe the data we assembled for empirical analysis. Further details are deferred to a data appendix.

\subsection{Data on Household Heads}

Following standard practice, we estimate the migration choice model using data on household heads. That is, we are assuming that the household heads are the decision makers when choosing a city to live in. Household data are drawn from the 1980 1\%, 1990 1\%, and 2000 5\% Integrated Public Use Microdata Series or IPUMS (Ruggles et al. 2010). For each household head, the census data provide rich information on demographic and economic variables such as race, age, gender, educational attainment, marital status, household composition, and income. The migration distance dummies can be generated using information on an individual's birth state and the metropolitan area where she or he currently lives.

Given two races and three census years, we construct six separate study samples to estimate migration choices. Cities are included in a study sample if they (1) are identifiable in IPUMS ${ }^{8}$ and (2) are not in Alaska or Hawaii, and (3) have at least 10,000 blacks (for black samples) or 1,000 blacks (for white samples). For black samples, we exclude cities with less than 10,000 blacks to make sure that any city in the sample is reasonably well represented in the sample of household heads. For white samples, we exclude cities with less than 1,000 blacks so that ghettos and segregation are empirically meaningful in these cities. In total, the number of cities included in black samples is 186 in 1980, 203 in 1990, and 211 in 2000. In white samples, this number is 258 in 1980, 281 in 1990, and 288 in 2000.

For each race in each census year, we randomly draw 20,000 household heads aged 25-35 who (i) are born in one of the 48 contiguous states plus the District of Columbia, (ii) are full-time workers, and (iii) live in one of the cities included in the study sample. ${ }^{9}$ To better match the scenario of the migration choice model, we focus on the younger age groups because the attributes of residential locations more likely reflect the tastes of these household heads. Also, the location choices of young people are more likely to be driven

\footnotetext{
${ }^{8}$ IPUMS assigns an identifier to an MSA only if its population is higher than 100,000.

${ }^{9}$ Table A1 illustrates the key attributes separately for black and white household heads in each year.
} 
by current local amenity differences. With these six samples in hand, we then estimate the migration choice model separately for blacks and whites for each of the three census years.

\subsection{Measure of Residential Segregation and City-Level Controls}

There are different measures of residential segregation (Massey and Denton 1988). In our analysis here, we focus on the widely used dissimilarity index. The dissimilarity index is defined as

$$
S_{j}=\frac{1}{2} \sum_{i=1}^{N}\left|\frac{\text { Black }_{i j}}{\text { Blacks }_{j}}-\frac{\text { Nonblacks }_{i j}}{\text { Nonblacks }_{j}}\right|,
$$

where $B l a c k s_{i j}$ is the number of blacks in neighborhood (i.e., census tract) $i$ in city $j$; Blacks $s_{j}$ is the total number of blacks in city $j$; Nonblacks $s_{i j}$ is the number of nonblacks in neighborhood $i$ in city $j$; and Nonblacks $_{j}$ is the total number of nonblacks in city $j .{ }^{10}$ This index ranges from 0 to 1 , with 0 indicating that every neighborhood has an equal share of blacks and nonblacks in the city, and 1 indicating that blacks and nonblacks never live in the same neighborhood.

We obtain the dissimilarity index data from Cutler et al. (1999) and Glaeser and Vigdor (2001), which are summarized in the second row of Table 1 . The mean dissimilarity index declines by approximately six percentage points every decade, from 62 percent in 1980 to 50 percent in 2000. Segregation varies substantially across cities, as indicated by the standard deviation of the dissimilarity index that is roughly 13 percent for each year. For example, the most segregated city in the 1980 sample is Fort Myers-Cape Coral, FL, with a dissimilarity index of 0.88 , while the least segregated city is Danville, VA, with a dissimilarity index of 0.31 .

Table 1 also presents the summary statistics of other city characteristics used in the second-step regressions. The first set of controls includes city population, the share of population that is black, population density, and median household income, all of which represent standard controls in the existing literature. Since more educated people may have a higher degree of tolerance toward unlike neighbors, we also control for local human capital level using the share of people aged 25 or over with a college or higher degree. Another control is the city-level Gini coefficient, which measures the level of income inequality. Since blacks on average are poorer than whites, higher income inequality may reflect a greater economic distance between blacks and whites, which tends to cause higher levels of segregation. As a final control, we also take into account the share of

\footnotetext{
${ }^{10}$ Although our discussion focuses on blacks and whites only, there are other minority groups living in each city. Here we lump other minority groups with whites and call them nonblacks. An alternative way to construct the index is to drop all other groups and only use the data on blacks and whites, which seems to be uncommon in the literature.
} 
labor employed in manufacturing, since labor shortages in American's older industrial cities spurred the first wave of black migration to urban areas.

\subsection{Identification}

\subsubsection{Predicting Individual Wages}

To predict $\hat{W}_{i j}$, we run a separate wage regression for each city to estimate city-specific returns to individual characteristics and then substitute each person's characteristics into the estimated city-specific wage equation. It should be noted, however, that simple OLS estimates of returns to individual characteristics may be biased due to nonrandom sorting of individuals across cities. To correct for this selection bias, we follow a semi-parametric estimation method proposed by Dahl (2002) and subsequently used by Bayer et al. (2009).

Consider the following wage equation for city $j$ :

$$
\ln W_{i j}=\alpha_{j}+\Gamma_{i} \rho_{j}+\varepsilon_{i j}
$$

where $\ln W_{i j}$ is the logarithm of individual $i$ 's wage in city $j ; \Gamma_{i}$ is a vector of individual characteristics; and $\varepsilon_{i j}$ is the error term. Since one can only obtain wage information for those who have actually chosen city $j$, the sample is not random, and in general

$$
E\left(\ln W_{i j} \mid \text { city } j \text { is chosen }\right)=\alpha_{j}+\Gamma_{i} \rho_{j}+E\left(\varepsilon_{i j} \mid \text { city } j \text { is chosen }\right) .
$$

The OLS estimate of $\rho_{j}$ is likely to be biased due to self-selection, i.e., $E\left(\varepsilon_{i j} \mid \cdot\right)$ and $\Gamma_{i}$ are correlated. Dahl (2002) shows that $E\left(\varepsilon_{i j} \mid \cdot\right)$ can be written as a function of $\left(P_{i 1}, P_{i 2}, \ldots, P_{i J}\right)$, where $P_{i k}, k=1,2, \ldots, J$, is the probability of individual $i$ moving to city $k$. To reduce the dimension of this function, Dahl invokes a "single index sufficiency assumption": If individual $i$ actually moved to city $j$, then the probability $P_{i j}$ alone would contain sufficient information to predict $E\left(\varepsilon_{i j} \mid \cdot\right)$. It follows that a consistent estimate of $\rho_{j}$ can be obtained from the following regression

$$
\ln W_{i j}=\alpha_{j}+\Gamma_{i} \rho_{j}+\psi_{j}\left(P_{i j}\right)+\pi_{i j}
$$

where $\psi_{j}\left(P_{i j}\right)$ is an unknown function of $P_{i j}$ that equals $E\left(\varepsilon_{i j} \mid \cdot\right)$. Dahl proposes that this unknown function can be approximated by a polynomial or Fourier series of $P_{i j}$. Since individual $i$ has indeed moved to city $j, P_{i j}$ can be estimated nonparametrically.

The data for wage regressions are taken from the 1980, 1990, and 2000 IPUMS. For each year, we select all blacks and whites aged 20 to 65 who (i) are born in one of the 48 contiguous states plus the District of Columbia, (ii) are full-time workers, and (iii) live in one of the cities included in that year's study samples. As suggested in Dahl (2002), 
we estimate $P_{i j}$ using the following method: For each year, we first assign all individuals into one of four educational groups: less than high school, high school, some college, and college degree or higher. Within each educational group, we then divide individuals into two racial groups: blacks and whites. Within each education by race group, we further classify individuals into nine census divisions by birth state. In total, we have 72 education-by-race-by-census-division data cells and each individual belongs to one of them. The migration probability $P_{i j}$ is calculated as the fraction of the population in individual $i$ 's cell that have migrated to city $j$.

We approximate $\psi_{j}\left(P_{i j}\right)$ with the second degree polynomial of $P_{i j}$ and estimate the following wage equation:

$$
\ln W_{i j}=\alpha_{j}+\Gamma_{i} \rho_{j}+\phi_{j 1} P_{i j}+\phi_{j 2} P_{i j}^{2}+\pi_{i j}
$$

where individual characteristics $\Gamma_{i}$ include age, age squared, and dummy variables for white, male, high school, some college, college degree or higher, and marital status. Note that when predicting individual wages, we exclude $P_{i j}$ and $P_{i j}^{2}$ from the calculation because they only serve as additional controls to correct for selection bias.

\subsubsection{Measuring Housing Price}

Next, we measure housing price at the city level. Recall that housing price will be used to construct the dependent variable in equation (8'), which then will be regressed on the level of segregation and other city characteristics to estimate $\beta_{s}$ and $\beta_{x}$. One possible way to measure housing price is to use a simple aggregate statistic such as the median housing price in a given city. However, such a measure is likely to be correlated with housing quality. Furthermore there are reasons to believe that housing quality is correlated with city characteristics. For example, Farley and Frey (1994) find that a city's level of segregation is negatively correlated with the share of new construction in housing stock, perhaps reflecting reduced racial discrimination in newer housing markets as a result of fair housing legislations. This correlation between segregation and housing quality implies that if median housing price is used, it is likely to produce a biased estimate of $\beta_{s}$.

To overcome this bias, following Bayer et al. (2009), we use a version of qualityadjusted housing price generated from the following housing-price regression:

$$
\ln P_{i j}^{H}=\ln p_{j}+\Omega_{i} \gamma+v_{i j}
$$

where $\ln P_{i j}^{H}$ is the logarithm of price for house $i$ in city $j ; \Omega_{i}$ is a vector of housing characteristics; and $v_{i j}$ is the error term. $\ln p_{j}$ represents a city-specific constant that 
captures quality-adjusted housing price in city $j$. Again, we utilize IPUMS data to estimate the housing-price regressions for 1980, 1990, and 2000 separately, and then use estimated $\ln p_{j}$ to replace $\ln p_{j}$ in equation ( $\left.8^{\prime}\right) .{ }^{11}$ For our baseline regressions, we estimate housing price using data on owner-occupied houses only. In robustness analysis, we will check whether including data on rental housing units affects our main results. See the data appendix for more details on the housing characteristics included in these regressions.

Note that in equation ( $\left.8^{\prime}\right)$, we only replace the $\ln p_{j}$ on the left side using the estimated housing price from equation (15). The share of income spent on housing, which is needed for estimating $\beta_{h}$ in equation (8'), is calculated using actual housing prices. Specifically, we assume that a house is financed by a fixed rate mortgage and the owner pays back the loan over 30 years (360 months). For each racial group in each census year, we calculate the monthly payment for each homeowner using the prevailing mortgage rate in that year. ${ }^{12}$ This monthly payment is then divided by the monthly income, and we use the sample average of this fraction as the estimated share of income spent on housing. These estimates are $0.35,0.24$, and 0.20 for whites in 1980, 1990, and 2000, respectively; and $0.27,0.20$, and 0.19 for blacks in 1980, 1990, and 2000, respectively. To be consistent with the estimation of equation (15), we only use the data on home owners here; we will incorporate data on renters in robustness analysis.

\subsubsection{Instrumenting for Residential Segregation}

To address the endogeneity of segregation, we draw two sets of instruments for segregation from the previous literature. The first set includes two fiscal instruments originally constructed and used by Cutler and Glaeser (1997): the number of municipal and township government units in 1962 and the share of local revenue that results from intergovernmental sources (state or federal) in 1962. The rationale for employing these variables is that households will sort themselves across jurisdictions in a Tiebout fashion to take advantage of local differences in tax rates and service provision. More local governments and less money from intergovernmental transfers will lead to larger variations in tax rates and service provision in an area, facilitate residential sorting among households, and thus tend to result in higher levels of segregation.

The second set of instruments includes two topographic variables developed by Hoxby (2000) and revised by Rothstein (2007): the number of inter- and intra-county rivers through one city. ${ }^{13}$ Rivers serve as natural boundaries that divide a city into subunits.

\footnotetext{
${ }^{11}$ In housing-price regressions for 1980, 1990, and 2000, we demean all housing characteristics variables in $\Omega_{i}$ so that $\ln p_{j}$ measures the price of the average house in that census year in city $j$.

${ }^{12}$ The 30 -year fixed mortgage rate we used are $13.74 \%$ for $1980,10.13 \%$ for 1990 , and $8.05 \%$ for 2000 .

${ }^{13}$ Hoxby (2000) analyzes the effect of Tiebout choice on school performance among districts using the number of large and small rivers as exogenous instrumental variables. Rothstein (2007) revisits Hoxby's
} 
Hence more rivers may increase segregation in a city by increasing the number of local governments or by providing natural barriers that impede the movement of blacks into white neighborhoods.

To illustrate the effects of these instruments on segregation, we separately regress the logarithm of the dissimilarity index on the two sets of instruments using the 1990 white sample. Columns 1-2 of Table 2 report the regression results and columns 3-6 give the summary statistics of instruments. All the coefficients for these instruments are statistically significant, suggesting that they satisfy the "relevance" condition of instrumental variables. All but one coefficient have the expected signs. The only exception is the negative coefficient on intra-county rivers, which shows that more intra-county rivers conditional on the number of inter-county rivers may slightly facilitate racial mixing.

\section{Empirical Results}

\subsection{Wage and Housing-Price Regressions}

Table A2 summarizes the estimated coefficients from the city-specific wage regressions for 1980,1990 , and 2000. In the average city, from 1980 to 2000, the wage gap between blacks and whites increases slightly, whereas the gender wage gap diminishes significantly. Wages increase with educational attainment. Since 1980, there has been a substantial increase in the premium on college degrees. The coefficients on age and age squared imply that wages increase with age, but at a decreasing rate. The positive coefficients on marital status suggest that married people tend to earn more, and this effect increases sightly over time.

Table A4 presents the estimates from the housing-price regression in each year, except that the estimates of quality-adjusted housing prices $\left(\ln p_{j}\right)$ are summarized in the first row of Table 1. As shown, almost all the estimates are statistically significant and have the expected signs. Newer houses, larger houses, and houses with complete kitchen and plumbing facilities have higher prices.

analysis and argues that the results in Hoxby (2000) are sensitive to some reasonable modifications such as the redefinition of large and small rivers. Rothstein provides five sets of measures for large and small rivers, under different definitions. We use inter- and intra-county rivers through one metropolitan area as our topographic instruments because they appear to be more strongly correlated with the level of segregation. 


\subsection{The First-Step Maximum Likelihood Estimates}

Panels A and B of Table 3 present the first-step maximum likelihood estimates for blacks and whites in 1980, 1990, and 2000, respectively. ${ }^{14}$ Since it is not feasible to list all the estimated city-level mean utilities $\left(\Theta_{j}\right)$, the first row in each panel presents the mean and standard deviation. For each sample, the mean utilities of cities are measured relative to that of Boston, MA, which is set equal to zero.

The estimates of the marginal utility of wage, shown in the second rows of each panel, are highly significant with the expected positive sign. With few exceptions, the coefficients on migration-distance dummies are also statistically significant. Specifically, they indicate that long-distance migration tends to result in utility losses. Migration costs appear to increase as an individual leaves his or her birth state, birth division, and birth region (for whites only) - although at a decreasing rate. For blacks, moving out of birth region has a positive and statistically significant coefficient for the 1980 and 1990 samples. This unexpected result may reflect the fact that a sizable number of young blacks in these two samples were born in the South but migrated to the North with their parents at very early ages, and thus had less emotional attachment to their birth places.

We allow the preference for segregation to vary with three individual attributes: a dummy variable that equals 1 if educational attainment is high school or less and 0 otherwise; a dummy variable that equals 1 if the household has any children and 0 otherwise; and the age of the household head. All three variables are demeaned by their sample averages so that the coefficient of segregation to be estimated at the second step $\left(\beta_{s}\right)$ represents the preference of the average household head in the sample.

The last three rows in each panel report the estimated coefficients on individual attributes interacted with the log dissimilarity index. The coefficients on age interacted with segregation are positive in almost every sample and are statistically significant for the 1980 black, 1990 black, and 1980 white samples, suggesting that older migrants tend to tolerate segregation more than younger migrants. For both blacks and whites in each year, there are no significant differences between less and more educated migrants in their preferences for segregation. The results in the last row show that in almost every case, migrants with children dislike segregation more than those without children. But this difference is statistically significant only for the 1990 and 2000 white samples.

\footnotetext{
${ }^{14}$ Since the estimated parameters in the logit model are scaled by the variance of the unobserved portion of utility $\left(\eta_{i j}\right.$ in equation $\left.(7)\right)$ and this variance is different in different samples, the absolute levels of the first- and second-step estimates cannot be directly compared across samples.
} 


\subsection{The Second-Step OLS Estimates}

Columns 1-6 of Table 4 show the second-step OLS estimates of equation (8') for blacks and whites in 1980, 1990, and 2000. We present the results from two parallel sets of regressions: one using all cities in each sample (panel A) and the other using a subset of cities available for both races and all three census years (panel B) to maintain a uniform sample size. To conserve space, except for our baseline specification in panel A, we only present the coefficients on the log dissimilarity index. Since the magnitude of a single estimate in the logit model cannot be directly compared across races and decades, we leave the discussion of race- and time-varying preferences for segregation and the economic significance of these estimates for next section when measuring households' marginal willingness to pay.

The OLS estimates of the mean preference for segregation are negative for both blacks and whites in all three census years. They are statistically significant in most samples. One exception worthy of note is that this negative coefficient is always insignificant for the 1980 blacks. Negative preferences for segregation suggest that segregation is associated with utility losses for both blacks and whites and that they would be willing to give up some income in exchange for a lower level of segregation in their cities of residence.

The estimated coefficients on other city characteristics shown in panel A also reveal useful information. From 1980 to 2000, both blacks and whites appear to prefer larger and more skilled cities. Although blacks dislike segregation, it seems that they prefer to reside in cities with higher black shares. In contrast, whites' preferences for living in a city with a higher share of blacks vary in sign and significance level over time. As expected, high-density is a disamenity. High-income cities also appear to be unattractive for both races, perhaps because it is disproportionatelly more expensive to live in such cities. Cities with low income inequalities are appealing for whites in each year and for blacks in 2000. Additionally, cities with a larger share of employment in the manufacturing sector appear to be unattractive in all but the 2000 black and white samples.

\subsection{The Second-Step 2SLS Estimates}

Table 5 presents the second-step 2SLS estimates for equation ( $\left.8^{\prime}\right)$ using fiscal and river instruments. Again, we run two sets of parallel regressions, one using all cities in each sample and the other imposing a uniform sample size. Panels A-B use fiscal instruments and $\mathrm{C}-\mathrm{D}$ use river instruments. In each regression, we include the same set of controls as in panel A of Table 4. Again, in each panel to conserve space we only report the coefficients of log dissimilarity index.

For all 2SLS regressions, we report the $F$-statistic that tests the joint significance of the instrumental variables in the first stage. As indicated, the fiscal instrumental 
variables are very strongly correlated with segregation. When used alone as instruments, they always have first-stage $F$-statistics higher than 10, the rule-of-thumb value for strong instruments. In contrast, when we use the river instrumental variables, the first-stage $F$ statistics are always lower than 10, suggesting the possibility of potential weak-instrument problems.

A valid instrumental variable should also be excludable. That is, the instrument (e.g., the number of local governments) has no effects on housing-price-adjusted cityspecific mean utilities other than through racial segregation. To assess the validity of our instruments, we perform the Hansen's J test. This test treats one of the excluded instruments as a truly exogenous variable and examines whether the other instruments are exogenous. For most specifications, fiscal and river instruments pass the overidentification test at the five percent level. Fiscal instruments perform poorly for the 1980 black sample and river instruments perform poorly for the 1980 and 1990 white samples.

We have also tried estimating equation (8') by combining fiscal and river instruments. The coefficients on segregation closely resemble those estimated using fiscal instruments only. ${ }^{15}$ Further exploration reveals that the effect of rivers on segregation diminishes substantially once we control for the number of local governments, suggesting that rivers affect segregation primarily through increases in the number of local governments.

Given all these results from diagnosis tests and exploratory analysis, we feel that the 2SLS estimates using the fiscal instruments are more reliable. We therefore consider the estimates in panels $\mathrm{A}$ and $\mathrm{B}$ of Table 5 as our preferred estimates. The estimates using the river instruments are presented mainly for comparison purposes. ${ }^{16}$

Panel A of Table 5 shows that the estimated mean preferences for segregation using fiscal instruments are all negative; and they are statistically significant for all but one sample (1980 blacks). This again indicates that both blacks and whites dislike segregation. Compared with the corresponding OLS estimates, the 2SLS estimates using fiscal instruments are much larger in magnitude, ranging from two times (for the 1980 black sample) to seven times (for the 1980 white sample) larger. In panel C of Table 5 , we see that the 2SLS coefficients using river instruments are less precisely estimated. The estimated mean preferences for segregation continue to be negative for all samples. However, they are almost always smaller in magnitude than those estimated using fiscal instruments, which seems consistent with the notion that they suffer from weak instrument biases. Results in panels B and D, estimated using the same subset of cities across

\footnotetext{
${ }^{15}$ A similar finding was noted by Cutler and Glaeser (1997), who studied the effects of segregation on the labor market and social outcomes of young blacks using the fiscal and river instruments.

${ }^{16}$ In addition, we also experimented with the idea of using long lags of dissimilarity index or the configuration of railroads in the 19th century (as in Ananat 2011) to instrument for segregation. However, in both cases, the sample of cities is considerably smaller and the effects of segregation cannot be estimated with reasonable precision. Thus we are not reporting the results from these exercises.
} 
different samples, are qualitatively similar to those estimated using the full sample for each city.

Overall, two points regarding the results in Tables $4-5$ are worth noting. First, these results generally suggest that ghettos are bad for both blacks and whites. For blacks, our findings complement previous studies that have documented many adverse effects of segregation on black outcomes. While previous studies focus on very specific outcomes of segregation on blacks, our results can be interpreted as an overall negative effect of segregation on both blacks and whites. Earlier studies tend to find that segregation has moderate positive effects (e.g., Cutler and Glaeser 1997) or mixed effects (e.g., Ananat 2011) on white outcomes. Our findings suggest that there are substantial neglected costs of segregation for whites. For instance, the presence of ghettos in a city may limit the choice of residential locations for white households and restrict their consumption of some desirable public goods (e.g., parks in predominantly black neighborhoods). It is also possible that the existence of a de facto apartheid contradicts the ideals of many whites and makes them feel uncomfortable. These unobserved "costs" for whites seem nontrivial and they should be explicitly taken into account in a welfare analysis of racial segregation.

Second, regression results indicate that the OLS estimates of the mean preference for segregation are generally biased downward in magnitude, suggesting that omitted city amenities (for both blacks and whites) are positively correlated with the level of segregation. There are several possible sources of this bias. First, older industrial cities in the North are more racially segregated, and they also tend to have a richer cultural and historical legacy that constitutes unmeasured city amenities to many people. Second, while segregation at the city level may represent a disamenity, it allows each racial group to build their own communities according to their own needs. For example, in predominantly black neighborhoods, more infrastructures can be constructed to facilitate leisure activities most preferred by blacks. Similar developments may also occur in predominantly white neighborhoods. These benefits from community-level specialization may help counter some of the negative effects of city-level segregation. And finally, there may be some local public policies that benefit both black and white residents but unintentionally intensify racial segregation. For example, increased investment in community development projects will better serve both black and white residents. However, if such projects are tailored to the dominant race in segregated neighborhoods, they could create a disincentive for integration. 


\subsection{Robustness Analysis}

In this section, we conduct robustness analysis to test the sensitivity of our main results, which is presented in Table 6. The first row reproduces the baseline estimates using fiscal instruments (from panel A of Table 5). Unless otherwise noted, the regression specifications for robustness analysis are the same as the baseline specifications.

\subsubsection{Omitted Regional Effects}

It is well known that, on average, cities in the Northeast and Midwest are more racially segregated and are characterized by the presence of more local governments than those in the South and West. This raises the concern whether the negative preferences for segregation are driven by omitted regional characteristics. One natural way to address this issue is to add region dummies to the baseline 2SLS specifications to control for cross-region differences. However, since within-region variations of segregation and instrumental variables are small, adding region dummies yields no (or weak) first-stage correlations between the $\log$ dissimilarity index and the fiscal instruments. ${ }^{17}$ Row 2 presents the results after adding region dummies. Most of the coefficients are still negative, but they are estimated with little precision and only one is statistically significant. That is, despite the concern for omitted regional characteristics, cross-region variations are crucial for estimating model parameters, and we cannot afford to throw them away and rely solely on region fixed effects regressions.

As a lesser test, we examine the extent to which our results are influenced by alternately dropping one of the four census regions. These results are reported in rows 3-6 of Table 6. In general, the estimates do not seem to be sensitive to dropping any of the four regions; in fact, they are qualitatively similar to the baseline estimates. In row 3 , when dropping the Northeast, the estimates are generally less negative than the baseline estimates. In rows 4-6, when dropping the Midwest, South, or West region, the estimates tend to be more negative than the baseline estimates. Overall, the estimates from dropping one region are more or less of the same order as the baseline results. Except for the 1980 black sample, estimates in rows 3-6 still clearly show that both blacks and whites dislike residential segregation.

\subsubsection{Competition among Jurisdictions}

Our preferred estimates use fiscal instruments. One possible threat to the validity of these instruments is competition among jurisdictions. In particular, increasing the number of governments may force governments to implement policies that are in accord with the

\footnotetext{
${ }^{17}$ With regional dummies, the first-stage $F$-statistics for the fiscal instruments range between 0.8 and 3.8 across different samples.
} 
interests of residents (e.g., Epple and Zelenitz 1981). Such policies could affect a city's attractiveness and thus influence individual utilities directly. To address this concern, we try adding two sets of controls in the baseline specifications. The first set is fiscal controls, including government expenditure per capita and property tax rate; the second set is related to local public services, including crime rate and high-school dropout rate. ${ }^{18}$ These results are presented in rows 7 and 8 . It appears that these controls do not qualitatively affect our main results. ${ }^{19}$

\subsubsection{The Share of Income Spent on Housing}

For the baseline regressions, we use the share of income spent on housing $\left(\beta_{h}\right)$, which was estimated to be between 0.19 and 0.35 across different samples. To test whether our main results are sensitive to this share, we rerun the regressions using an artificially high share value of 0.40 and an artificially low share value of 0.15 . These results, presented in rows 9 and 10, are qualitatively similar to the baseline estimates, although the magnitudes are slightly larger when using a high share of 0.40 and slightly smaller when using a low share of 0.15 .

In our baseline regressions, both the share of income in housing expenditure and the quality-adjusted housing price are estimated using information on home owners and their houses only; data on renters and rental units are ignored. Here we try to incorporate data on renters. For quality adjusted housing price, we add a rental unit dummy to equation (15) and run the regression using data on both owner-occupied houses and rental units. Again, the quality-adjusted housing price is the estimated city-specific constant $\ln p_{j}$. For each renter, we calculate the share of income spent on housing by dividing monthly rent by monthly income. For homeowners, this share is calculated in the same way as described in the data section. We then average this share over all homeowners and renters, which is then used to calculate $\beta_{h}$ in equation ( $\left.8^{\prime}\right)$. Row 11 of Table 6 shows the coefficients of $\log$ dissimilarity index from this alternative estimation method, which are more or less the same as the baseline estimates.

\subsubsection{Endogeneity of Black Population Share}

Another concern is that a higher share of blacks in a city may reflect unobserved city characteristics that are particularly attractive to blacks. Although the coefficient of log

\footnotetext{
${ }^{18}$ The data for government expenditure, property tax rate, and crime rate come from the 1988, 1994, and 2000 editions of the City and County Databook. High-school dropout rate is measured as the share of individuals aged 16-19 who are neither in school nor high school graduates, which is calculated using the decennial census data from IPUMS.

${ }^{19}$ Also, interjurisdictional competition seems most likely to be an amenity. Thus its correlation with segregation tends to bias our baseline estimates toward zero. In that case, the true preferences for segregation could be even more negative than estimated here.
} 
black share is not the focus of this study, the endogeneity of black share - similar to that of housing price - may spill over to the estimate of $\beta_{s}$, the key parameter of interest for this study. In row 12, we use the black share in 1890 to instrument for current black share in 1980, 1990, and 2000. The 1890 black share is unlikely to be correlated with omitted city variables for the 1980-2000 samples because that year predates the first wave of black migration from the rural South to the urban North (Cutler et al. 1999). ${ }^{20}$ Although the sample size drops to roughly 120 cities for all six samples, the estimates are very similar to the baseline estimates.

Overall, these sensitivity analyses suggest that except for the 1980 blacks, the baseline estimates are robust to a variety of alternative specifications. We have also learned that cross-region variations are necessary for estimating key model parameters, and that one has to keep this in mind when interpreting the results.

\subsection{Marginal Willingness to Pay}

We now use our estimates to calculate the marginal willingness to pay (MWTP) for segregation. ${ }^{21}$ For individual $i$ living in city $j$, the MWTP is defined as

$$
M W T P_{i j}=\frac{\partial V_{i j} / \partial S_{j}}{\partial V_{i j} / \partial W_{i j}}=\frac{\beta_{i s}}{\beta_{w}} \frac{W_{i j}}{S_{j}}=\frac{\beta_{s}+\sum_{c} z_{i c} \beta_{s c}}{\beta_{w}} \frac{W_{i j}}{S_{j}} .
$$

For simplicity, we suppress the race and year subscripts here. The first equality represents the standard definition of MWTP in the literature (Rosen 1974; Roback 1982), i.e., the implicit price of segregation equals the marginal rate of substitution between segregation and income at a given utility level. Replacing $\partial V_{i j} / \partial S_{j}$ and $\partial V_{i j} / \partial W_{i j}$ with parameters in the indirect utility function (equation (3)) yields the second equality and allowing for heterogeneous preferences for segregation gives the third equality. As this formula indicates, MWTP varies with individual characteristics, increases with income, and decreases with the chosen city's segregation level.

To facilitate comparisons across races and census years, we separately calculate the MWTP of a representative black and a representative white using the 1990 median household income $\left(W_{i j}=\$ 35,763\right.$ in 1999 dollars) and the 1990 mean dissimilarity index $\left(S_{j}=0.568\right) . \beta_{w}$ and $\beta_{s c}$ are taken from Table 3 . Table 7 reports the estimated marginal willingness to pay by blacks and whites for a one-percentage-point reduction in the dis-

\footnotetext{
${ }^{20}$ The data for black share in 1890 also come from Cutler et al. (1999), where it is measured at the central city level because data at the metropolitan area level were not available at that time.

${ }^{21}$ Marginal willingness to pay is the appropriate welfare measure for marginal changes in segregation. However, for non-marginal changes, households may be better off by changing residential locations, and housing suppliers may be better off by adjusting the quality or quantity of housing supply. Hence, the estimated willingness to pay at the originally chosen location will underestimate the total true benefits or costs. See Bartik (1988) for an extended discussion of these issues.
} 
similarity index - a change in the residential pattern that would involve relocating one percent of blacks in the city from their current neighborhoods to less segregated neighborhoods. The first and second rows present the mean MWTP calculated using the baseline OLS and 2SLS (with fiscal instruments) estimates of $\beta_{s}$, i.e., coefficients of log dissimilarity index from panel A of Tables 4 and 5). It is clear that the estimated mean MWTP increases substantially for both blacks and whites after instrumenting for segregation. Moving across the columns in row 2, we see that the mean MWTP of blacks rises from $\$ 89$ in 1980 to $\$ 436$ in 2000, and becomes higher than that of whites starting from 1990. Given that the mean preferences for segregation are not precisely estimated for the 1980 blacks as shown in the preceding section, we should interpret this result as, at best, suggestive time-varying preferences among blacks. However, this finding appears to be reasonable and is indeed consistent with the widely held view that ghettos have become worse places for blacks. It is also consistent with Wilson's (1987) thesis that the continued exodus of better educated blacks has had a devastating effect on ghettos over time.

For whites, the mean MWTP falls from $\$ 675$ to $\$ 301$ between 1980 and 2000, indicating that over the past few decades whites have become less uncomfortable when living in segregated cities. One plausible interpretation may be whites' attitudinal changes toward blacks. Survey data consistently show that there has been a decline in whites' distaste for neighborhoods with a sizable number of blacks (Schuman et al. 1997; Charles 2003). When whites exhibit a higher tolerance level for blacks in general, they may not feel very uncomfortable with the existence of ghettos and thus decrease their willingness to dismantle ghettos.

Rows 3-5 report the heterogeneity in MWTP for segregation, calculated from the estimated coefficients on individual attributes interacted with segregation (in Table 3). Only some of these estimates are economically significant. For example, in the 1990 black sample, blacks who are one year younger are willing to pay $\$ 30$ more. In other words, there is a $\$ 300$ difference in the MWTP between 25 and 35 year old blacks. In the 1990 white sample, whites with children are willing to pay $\$ 31$ more than those without children. In every sample, the effects of education on MWTP are economically insignificant. That is, blacks or whites at different education levels have rather similar negative preferences for segregation.

\section{Conclusion}

Unlike previous studies that focus on the effects of segregation on a limited number of observed outcomes, this paper estimates the overall effects including both observed and unobserved effects of segregation. This is made possible by adopting a method that 
treats racial segregation at the city level as an urban disamenity and allows for estimating people's willingness to pay for different degrees of segregation. Because the estimates in this paper capture the overall effects of segregation and because they are calculated for both blacks and whites, they are more suitable for welfare analysis.

Our empirical analysis provides new evidence that over the 1980-2000 period, ghettos are bad not only for young blacks, but also for young whites. The estimated mean preferences for less segregation are economically significant. For a one-percentage-point reduction in the dissimilarity index, the average black is willing to pay $\$ 529$ in 1990 and $\$ 436$ in 2000; the average white is willing to pay $\$ 675$ in $1980, \$ 430$ in 1990 , and $\$ 301$ in 2000. These findings suggest that reducing segregation at the city level could generate substantial social benefits for both blacks and whites.

\section{Data Appendix}

\section{Household Data}

Data on internal migrants are drawn from the 1980 1\%, 1990 1\%, and 2000 5\% Integrated Public Use Microdata Series (IPUMS). For blacks in each census year and whites in each census year, we randomly draw 20,000 household heads aged 25-35 who (i) are born in one of the 48 contiguous states plus the District of Columbia, (ii) work at least an average of 20 hours per week, (iii) work at least 10 weeks for pay in the previous year, (iv) earn at least 2,000 dollars (in 1999 dollars), and (v) live in one of the identifiable metropolitan areas in IPUMS. For black samples, we only select the metropolitan areas with at least 10,000 blacks. For white samples, we only select the metropolitan areas with at least 1,000 blacks. Some descriptive statistics of these household heads are shown in Table A1.

\section{Data Samples for Wage and Housing-Price Regressions}

The data for wage and housing-price regressions also come from the 1980 1\%, 1990 1\%, and 2000 5\% IPUMS. For wage regressions, we select all blacks and whites aged 20-65 who satisfy the same sample selection criteria (i)-(v) as just described above.

For baseline housing-price regressions, we only select owner-occupied houses that are located in one of the identified metropolitan areas in IPUMS. Housing characteristics include the number of rooms, units in a structure, the number of bedrooms, acreage of property, age of structure, available kitchen and plumbing facilities. We exclude the houses with one room and those with a missing price. Mean housing characteristics are presented in Table A3. In our robustness analysis, we also make use of the data on rental units. 


\section{Segregation Data and Instrumental Variables}

From Cutler et al. (1999) and Glaeser and Vigdor (2001), we obtain the dissimilarity index, city population, and the percent of city population that is black in 1980, 1990, and 2000, which they originally calculated or drew from the decennial census data. Our fiscal instruments, number of governments and government revenue sharing in 1962, come from Cutler and Glaeser (1997), who constructed the variables using data from Census of Governments. To count the number of governments, they include all municipal and township governments in the boundary of an MSA as defined in 1990. To measure the share of local government revenue that comes from intergovernmental transfers, they first calculate this share for all local governments and then take the average over all local governments in each state. They use the same state average share for all the cities in the state. All these data from Cutler and Glaeser (1997), Cutler et al. (1999), and Glaeser and Vigdor (2001) are available at the following website: http: //web.archive.org/web/20031005171713/trinity.aas.duke.edu/ jvigdor/segregation. Our topographic instruments come from Rothstein (2007) and are available at his web page: http://gsppi.berkeley.edu/faculty/jrothstein. We use the numbers of inter- and intracounty rivers through a metropolitan area, as per Rothstein's definition.

\section{Other Metropolitan Area Controls}

We include a number of other metropolitan area controls. The first three control variables are median household income, the share of workers employed in manufacturing, and the share of adults aged 25 or older with a college or higher degree. These three variables are either calculated using the 1\% IPUMS data (for 1980) or directly drawn from the decennial census summary tape files (for 1990 and 2000). The fourth control is population density, which is calculated by dividing metropolitan area population by land area. The data for land area is taken from the 1990 U.S. Gazetteer Files. For metropolitan areas in 1980, 1990, and 2000, we aggregate county-level land area for non-New England metropolitan areas, and aggregate city- and town-level land area for New England metropolitan areas.

The final control is the Gini coefficient. Following Glaeser et al. (2009), the Gini coefficient for one city is defined as $1-\frac{1}{\hat{y}} \int_{y}(1-F(y))^{2} \mathrm{~d} y$, where $\hat{y}$ is mean income and $F(y)$ is the share of population with income less than $y$. The value of the Gini coefficient ranges between 0 and 1, with 0 indicating complete equality and 1 indicating extreme inequality. We measure Gini coefficients using total household income from the 1980 1\%, 1990 1\%, and 2000 5\% IPUMS. The census income is top coded at $\$ 75,000$ in $1980, \$ 400,000$ in 1990 , and $\$ 999,998$ in 2000 . We use top-coded income, which will underestimate Gini coefficients. 


\section{References}

Ananat, Elizabeth Oltmans. 2011. "The Wrong Side(s) of the Tracks: The Causal Effects of Racial Segregation on Urban Poverty and Inequality." American Economic Journal: Applied Economics 3 (2): 34-66.

Bajari, Patrick and Matthew E. Kahn. 2005. "Estimating Housing Demand With an Application to Explaining Racial Segregation in Cities." Journal of Business 65 Economic Statistics 23 (1): 20-33.

Bartik, Timothy J. 1988. "Measuring the Benefits of Amenity Improvements in Hedonic Price Models." Land Economics 64 (2): 172-183.

Bayer, Patrick, Fernando Ferreira, and Robert McMillan. 2007. "A Unified Framework for Measuring Preferences for Schools and Neighborhoods." Journal of Political Economy 115 (4): 588-638.

Bayer, Patrick, Nathaniel Keohane, and Christopher Timmins. 2009. "Migration and Hedonic Valuation: The Case of Air Quality." Journal of Environmental Economics and Management 58 (1): 1-14.

Berry, Steven, James Levinsohn, and Ariel Pakes. 1995. "Automobile Prices in Market Equilibrium." Econometrica 63 (4): 841-890.

Berry, Steven T. 1994. "Estimating Discrete-Choice Models of Product Differentiation." RAND Journal of Economics 25 (2): 242-262.

Borjas, George J. 1995. "Ethnicity, Neighborhoods, and Human-Capital Externalities." American Economic Review 85 (3): 365-390.

Card, David and Jesse Rothstein. 2007. "Racial Segregation and the Black-White Test Score Gap." Journal of Public Economics 91 (11-12): 2158-2184.

Charles, Camille Zubrinsky. 2003. "The Dynamics of Racial Residential Segregation." Annual Review of Sociology 29: 167-207.

Cutler, David M. and Edward L. Glaeser. 1997. "Are Ghettos Good or Bad?" Quarterly Journal of Economics 112 (3): 827-872.

Cutler, David M., Edward L. Glaeser, and Jacob L. Vigdor. 1999. "The Rise and Decline of the American Ghetto." Journal of Political Economy 107 (3): 455-506.

Dahl, Gordon B. 2002. "Mobility and the Return to Education: Testing a Roy Model with Multiple Markets." Econometrica 70 (6): 2367-2420.

Ellwood, David T. 1986. "The Spatial Mismatch Hypothesis: Are There Teenage Jobs Missing in the Ghetto?" In The Black Youth Employment Crisis, edited by Richard B. Freeman and Harry J. Holzer. Chicago: University of Chicago Press.

Epple, Dennis and Allan Zelenitz. 1981. "The Implications of Competition among Jurisdictions: Does Tiebout Need Politics?" Journal of Political Economy 89 (6): 11971217. 
Farley, Reynolds and William H. Frey. 1994. "Changes in the Segregation of Whites from Blacks During the 1980s: Small Steps Toward a More Integrated Society." American Sociological Review 59 (1): 23-45.

Ferreira, Fernando. 2010. "You Can Take It With You: Proposition 13 Tax Benefits, Residential Mobility, and Willingness to Pay for Housing Amenities." Journal of Public Economics 94 (9-10): 661-673.

Glaeser, Edward L., Matt Resseger, and Kristina Tobio. 2009. "Inequality in Cities." Journal of Regional Science 49 (4): 617-646.

Glaeser, Edward L. and Jacob L. Vigdor. 2001. Racial Segregation in the 2000 Census: Promising News. Washington, D.C.: Brookings Institution, Center on Urban and Metropolitan Policy.

Hoxby, Caroline M. 2000. "Does Competition among Public Schools Benefit Students and Taxpayers?" American Economic Review 90 (5): 1209-1238.

Ihlanfeldt, Keith R. and David L. Sjoquist. 1990. "Job Accessibility and Racial Differences in Youth Employment Rates." American Economic Review 80 (1): 267-276.

Kain, John F. 1968. "Housing Segregation, Negro Employment, and Metropolitan Decentralization." Quarterly Journal of Economics 82 (2): 175-197.

Kasarda, John D. 1989. "Urban Industrial Transition and the Underclass." ANNALS of the American Academy of Political and Social Science 501 (1): 26-47.

Krivo, Lauren J., Ruth D. Peterson, and Danielle C. Kuhl. 2009. "Segregation, Racial Structure, and Neighborhood Violent Crime." American Journal of Sociology 114 (6): 1765-1802.

Logan, John, Brian Stults, and Reynolds Farley. 2004. "Segregation of Minorities in The Metropolis: Two Decades of Change." Demography 41 (1): 1-22.

Massey, Douglas S. and Nancy A. Denton. 1988. "The Dimensions of Residential Segregation." Social Forces 67 (2): 281-315.

Massey, Douglas S. and Nancy A. Denton. 1993. American Apartheid: Segregation and the Making of the Underclass. Cambridge: Harvard University Press.

Roback, Jennifer. 1982. "Wages, Rents, and the Quality of Life." Journal of Political Economy 90 (6): 1257-1278.

Rosen, Sherwin. 1974. "Hedonic Prices and Implicit Markets: Product Differentiation in Pure Competition." Journal of Political Economy 82 (1): 34-55.

Rothstein, Jesse. 2007. "Does Competition among Public Schools Benefit Students and Taxpayers? Comment." American Economic Review 97 (5): 2026-2037.

Ruggles, Steven, J. Trent Alexander, Katie Genadek, Ronald Goeken, Matthew B. Schroeder, and Matthew Sobek. 2010. Integrated Public Use Microdata Series: Version 5.0 [Machine-readable database]. Minneapolis: University of Minnesota.

Schelling, Thomas C. 1971. "Dynamic Models of Segregation." Journal of Mathematical 
Sociology 1 (2): 143-186.

Schuman, Howard. 1997. Racial attitudes in America: Trends and interpretations. Cambridge: Harvard University Press.

Shihadeh, Edward S. and Nicole Flynn. 1996. "Segregation and Crime: The Effect of Black Social Isolation on the Rates of Black Urban Violence." Social Forces 74 (4): $1325-1352$.

Timmins, Christopher. 2007. "If You cannot Take the Heat, Get Out of the Cerrado...Recovering the Equilibrium Amenity Cost of Nonmarginal Climate Change in Brazil." Journal of Regional Science 47 (1): 1-25.

Weinberg, Bruce A. 2000. "Black Residential Centralization and the Spatial Mismatch Hypothesis." Journal of Urban Economics 48 (1): 110-134.

Williams, David R and Chiquita Collins. 2001. "Racial Residential Segregation: A Fundamental Cause of Racial Disparities in Health." Public Health Reports 116 (5): 404-416.

Wilson, William J. 1987. The Truly Disadvantaged: The Inner City, the Underclass, and Public Policy. Chicago: University of Chicago Press.

Wong, Maisy. 2013. "Estimating Ethnic Preferences Using Ethnic Housing Quotas in Singapore." Review of Economic Studies 80 (3): 1178-1214.

Zhang, Junfu. 2011. "Tipping And Residential Segregation: A Unified Schelling Model." Journal of Regional Science 51 (1): 167-193. 
Table 1: Summary Statistics for City-Level Variables

\begin{tabular}{|c|c|c|c|c|c|c|c|}
\hline \multirow[b]{2}{*}{ Variable } & \multirow[b]{2}{*}{ Description } & \multicolumn{2}{|c|}{1980} & \multicolumn{2}{|c|}{1990} & \multicolumn{2}{|c|}{2000} \\
\hline & & Mean & Std. Dev. & Mean & Std. Dev. & Mean & Std. Dev. \\
\hline $\ln$ (Housing price) & $\ln$ (Housing price) & 11.380 & 0.282 & 11.445 & 0.430 & 11.557 & 0.338 \\
\hline Dissimilarity index & Dissimilarity index & 0.624 & 0.122 & 0.568 & 0.127 & 0.502 & 0.134 \\
\hline Population & Populations in millions & 0.624 & 1.051 & 0.659 & 1.046 & 0.763 & 1.206 \\
\hline Black share & The percent of population that is black & 0.109 & 0.094 & 0.108 & 0.094 & 0.114 & 0.104 \\
\hline Population density & Population per square kilometer of land area & 180 & 359 & 190 & 357 & 185 & 379 \\
\hline College share & $\begin{array}{l}\text { The share of adults aged } 25+\text { with a college } \\
\text { or higher degree }\end{array}$ & 0.161 & 0.055 & 0.201 & 0.066 & 0.239 & 0.074 \\
\hline Gini & Gini coefficients & 0.376 & 0.021 & 0.406 & 0.025 & 0.435 & 0.026 \\
\hline Median household income & Median household income in thousands & 34.716 & 5.068 & 38.213 & 8.182 & 40.297 & 7.672 \\
\hline Manufacturing share & $\begin{array}{l}\text { The share of labor employed in manufacturing } \\
\text { industry }\end{array}$ & 0.234 & 0.096 & 0.179 & 0.072 & 0.143 & 0.066 \\
\hline
\end{tabular}

Notes: This table reports the summary statistics of city characteristics for white samples, which include 258, 281, and 288 cities in 1980, 1990, and 2000, respectively. The numbers of cities in black samples are smaller, but there are no statistically significant differences in the mean city characteristics between black and white samples for each year. All money values are in 1999 U.S. dollars. 
Table 2: Dissimilarity Index and Instruments

\begin{tabular}{lcccccc}
\hline & \multicolumn{2}{c}{ Log of the dissimilarity index } & Mean & Std. Dev. & Min & Max \\
& $(1)$ & $(2)$ & $(3)$ & $(4)$ & $(5)$ & $(6)$ \\
\hline ln(The number of governments) & $\begin{array}{c}0.094^{* * *} \\
(0.013)\end{array}$ & & 41 & 55 & 1 & 339 \\
Intergovernmental revenue share & $\begin{array}{c}-0.551^{* * *} \\
(0.201)\end{array}$ & & 0.238 & 0.078 & 0.123 & 0.494 \\
Inter-county rivers & & $0.0024^{* * *}$ & 44 & 35 & 0 & 215 \\
Intra-county rivers & & $(0.0005)$ & & & & \\
Constant & & $-0.00028^{*}$ & 116 & 128 & 0 & 812 \\
& $-0.682^{* * *}$ & $-0.00015)$ & & & & \\
\hline$R^{2}$ & $(0.078)$ & $(0.022)$ & & & & \\
Observations & 0.314 & 0.069 & & & & \\
\hline
\end{tabular}

Notes: Columns 1-2 report the results of regressing the logarithm of the dissimilarity index on each set of instruments using the 1990 white sample. Robust standard errors adjusted for heterogeneity are in parentheses.

Columns $3-6$ give the summary statistics of the corresponding instruments.

${ }^{*} p<0.10,{ }^{* *} p<0.05,{ }^{* * *} p<.01$ 
Table 3: First-Step Maximum Likelihood Estimates

\begin{tabular}{|c|c|c|c|c|c|c|}
\hline & \multicolumn{2}{|r|}{1980} & \multicolumn{2}{|r|}{1990} & \multicolumn{2}{|c|}{2000} \\
\hline & Estimates & Standard errors & Estimates & Standard errors & Estimates & Standard errors \\
\hline \multicolumn{7}{|l|}{ Panel A. Blacks } \\
\hline Mean utilities from city $j\left(\Theta_{j}\right)$ & -1.231 & 1.197 & -1.048 & 1.321 & -0.901 & 1.213 \\
\hline Marginal utility of wage $\left(\beta_{w}\right)$ & $3.156^{* * *}$ & 0.042 & $2.511^{* * *}$ & 0.042 & $2.747 * * *$ & 0.043 \\
\hline Out of birth state $\left(m_{1}\right)$ & $-3.013^{* * *}$ & 0.028 & $-3.165^{* * *}$ & 0.027 & $-3.208^{* * *}$ & 0.027 \\
\hline Out of birth division $\left(m_{2}\right)$ & $-1.591^{* * *}$ & 0.042 & $-1.301 * * *$ & 0.040 & $-1.182^{* * *}$ & 0.040 \\
\hline Out of birth region $\left(m_{3}\right)$ & $0.599^{* * *}$ & 0.042 & $0.292^{* * *}$ & 0.037 & 0.025 & 0.037 \\
\hline $\mathrm{Age}^{*} \ln S_{j}$ & $0.093^{* * *}$ & 0.015 & $0.118^{* * *}$ & 0.013 & 0.019 & 0.013 \\
\hline High school or less dummy* $\ln S_{j}$ & -0.091 & 0.096 & -0.064 & 0.084 & 0.066 & 0.082 \\
\hline The presence of children dummy* $\ln S_{j}$ & 0.016 & 0.098 & -0.023 & 0.087 & -0.138 & 0.086 \\
\hline \multicolumn{7}{|l|}{ Panel B. Whites } \\
\hline Mean utilities from city $j\left(\Theta_{j}\right)$ & -1.885 & 1.036 & -0.987 & 1.080 & -1.123 & 0.978 \\
\hline Marginal utility of wage $\left(\beta_{w}\right)$ & $3.509^{* * *}$ & 0.046 & $4.284^{* * *}$ & 0.045 & $3.531^{* * *}$ & 0.044 \\
\hline Out of birth state $\left(m_{1}\right)$ & $-2.800 * * *$ & 0.026 & $-2.815^{* * *}$ & 0.027 & $-2.885^{* * *}$ & 0.026 \\
\hline Out of birth division $\left(m_{2}\right)$ & $-0.895^{* * *}$ & 0.037 & $-0.762^{* * *}$ & 0.036 & $-0.705^{* * *}$ & 0.036 \\
\hline Out of birth region $\left(m_{3}\right)$ & $-0.478^{* * *}$ & 0.033 & $-0.631^{* * *}$ & 0.033 & $-0.637^{* * *}$ & 0.032 \\
\hline Age* $^{*} \ln S_{j}$ & $0.031^{* *}$ & 0.014 & -0.010 & 0.013 & 0.010 & 0.010 \\
\hline High school or less dummy ${ }^{*} \ln S_{j}$ & -0.016 & 0.087 & 0.095 & 0.080 & 0.023 & 0.066 \\
\hline The presence of children dummy ${ }^{*} \ln S_{j}$ & -0.123 & 0.088 & $-0.212^{* * *}$ & 0.078 & $-0.258^{* * *}$ & 0.065 \\
\hline
\end{tabular}

Notes: The first rows of panels $\mathrm{A}$ and $\mathrm{B}$ present the mean and standard deviation of estimated $\Theta_{j}$ in 1980, 1990, and 2000.

${ }^{*} p<0.10,{ }^{* *} p<0.05,{ }^{* * *} p<.01$ 
Table 4: Second-Step OLS Regression Results

(Dependent variable: $\Theta_{j}+\beta_{h} \ln p_{j}$, housing price adjusted mean utilities from city $j$ )

\begin{tabular}{|c|c|c|c|c|c|c|}
\hline & \multicolumn{3}{|c|}{ Blacks } & \multicolumn{3}{|c|}{ Whites } \\
\hline & $\begin{array}{c}1980 \\
(1)\end{array}$ & $\begin{array}{c}1990 \\
(2)\end{array}$ & $\begin{array}{c}2000 \\
(3)\end{array}$ & $\begin{array}{c}1980 \\
(4)\end{array}$ & $\begin{array}{c}1990 \\
(5)\end{array}$ & $\begin{array}{c}2000 \\
(6)\end{array}$ \\
\hline \multicolumn{7}{|l|}{ Panel A. Baseline: all cities } \\
\hline $\ln ($ Dissimilarity index $)$ & $\begin{array}{l}-0.232 \\
(0.289)\end{array}$ & $\begin{array}{c}-1.006^{* * *} \\
(0.193)\end{array}$ & $\begin{array}{c}-0.769^{* * *} \\
(0.189)\end{array}$ & $\begin{array}{c}-0.578^{* *} \\
(0.268)\end{array}$ & $\begin{array}{c}-0.852^{* * *} \\
(0.188)\end{array}$ & $\begin{array}{c}-0.472^{* * *} \\
(0.168)\end{array}$ \\
\hline $\ln$ (Population) & $\begin{array}{c}1.090^{* * *} \\
(0.064)\end{array}$ & $\begin{array}{c}1.137^{* * *} \\
(0.058)\end{array}$ & $\begin{array}{c}1.046^{* * *} \\
(0.044)\end{array}$ & $\begin{array}{c}1.069^{* * *} \\
(0.061)\end{array}$ & $\begin{array}{c}1.045^{* * *} \\
(0.052)\end{array}$ & $\begin{array}{c}0.997^{* * *} \\
(0.051)\end{array}$ \\
\hline $\ln$ (Black share) & $\begin{array}{c}0.430^{* * *} \\
(0.058)\end{array}$ & $\begin{array}{c}0.837^{* * *} \\
(0.074)\end{array}$ & $\begin{array}{c}0.901^{* * *} \\
(0.058)\end{array}$ & $\begin{array}{c}-0.244^{* * *} \\
(0.062)\end{array}$ & $\begin{array}{c}-0.133^{* *} \\
(0.057)\end{array}$ & $\begin{array}{c}0.041 \\
(0.060)\end{array}$ \\
\hline $\ln$ (Population density) & $\begin{array}{c}0.018 \\
(0.076)\end{array}$ & $\begin{array}{c}-0.157^{*} \\
(0.080)\end{array}$ & $\begin{array}{c}-0.201^{* * *} \\
(0.057)\end{array}$ & $\begin{array}{c}-0.072 \\
(0.063)\end{array}$ & $\begin{array}{c}-0.161^{* *} \\
(0.074)\end{array}$ & $\begin{array}{c}-0.211^{* * *} \\
(0.063)\end{array}$ \\
\hline $\ln ($ College share $)$ & $\begin{array}{c}0.330^{*} \\
(0.193)\end{array}$ & $\begin{array}{c}0.413 \\
(0.296)\end{array}$ & $\begin{array}{c}0.783^{* * *} \\
(0.217)\end{array}$ & $\begin{array}{c}0.476^{* * *} \\
(0.179)\end{array}$ & $\begin{array}{c}0.499^{* *} \\
(0.243)\end{array}$ & $\begin{array}{c}0.918^{* * *} \\
(0.262)\end{array}$ \\
\hline $\ln ($ Gini) & $\begin{array}{l}1.086 \\
(1.375)\end{array}$ & $\begin{array}{c}0.826 \\
(1.143)\end{array}$ & $\begin{array}{c}-1.486^{*} \\
(0.777)\end{array}$ & $\begin{array}{l}-0.718 \\
(1.100)\end{array}$ & $\begin{array}{l}-0.171 \\
(0.919)\end{array}$ & $\begin{array}{c}-3.224^{\text {*** }} \\
(0.841)\end{array}$ \\
\hline $\ln ($ Median household income) & $\begin{array}{c}0.147 \\
(0.594)\end{array}$ & $\begin{array}{l}-0.219 \\
(0.532)\end{array}$ & $\begin{array}{c}-0.839^{* *} \\
(0.413)\end{array}$ & $\begin{array}{c}-1.124^{* *} \\
(0.460)\end{array}$ & $\begin{array}{c}-1.248^{* * *} \\
(0.404)\end{array}$ & $\begin{array}{c}-2.081^{* * *} \\
(0.394)\end{array}$ \\
\hline $\ln$ (Manufacturing share) & $\begin{array}{c}-0.526^{* * *} \\
(0.147)\end{array}$ & $\begin{array}{c}-0.398^{* * *} \\
(0.116)\end{array}$ & $\begin{array}{c}0.061 \\
(0.077)\end{array}$ & $\begin{array}{c}-0.588^{* * *} \\
(0.124)\end{array}$ & $\begin{array}{c}-0.478^{* * *} \\
(0.148)\end{array}$ & $\begin{array}{l}-0.041 \\
(0.087)\end{array}$ \\
\hline Constant & $\begin{array}{l}-4.675 \\
(5.825)\end{array}$ & $\begin{array}{l}-4.370 \\
(5.269)\end{array}$ & $\begin{array}{c}3.322 \\
(4.253)\end{array}$ & $\begin{array}{c}10.975^{* *} \\
(4.736)\end{array}$ & $\begin{array}{c}11.638^{* * *} \\
(4.114)\end{array}$ & $\begin{array}{c}16.831^{* * *} \\
(4.142)\end{array}$ \\
\hline$R^{2}$ & 0.813 & 0.774 & 0.823 & 0.799 & 0.747 & 0.753 \\
\hline Observations & 176 & 203 & 184 & 185 & 203 & 185 \\
\hline \multicolumn{7}{|c|}{ Panel B. a subset of cities available for both race and all decades } \\
\hline $\ln ($ Dissimilarity index $)$ & $\begin{array}{l}-0.289 \\
(0.329)\end{array}$ & $\begin{array}{c}-1.093^{* * *} \\
(0.221)\end{array}$ & $\begin{array}{c}-0.802^{\text {*** }} \\
(0.200)\end{array}$ & $\begin{array}{l}-0.485 \\
(0.342)\end{array}$ & $\begin{array}{c}-0.861^{\text {*** }} \\
(0.208)\end{array}$ & $\begin{array}{c}-0.518^{* * *} \\
(0.179)\end{array}$ \\
\hline$R^{2}$ & 0.822 & 0.805 & 0.827 & 0.789 & 0.761 & 0.759 \\
\hline Observations & 161 & 161 & 161 & 161 & 161 & 161 \\
\hline
\end{tabular}

Notes: Robust standard errors adjusted for heterogeneity are in parentheses. Although not presented, each regression in panel $\mathrm{B}$ includes the same set of controls as in panel A.

${ }^{*} p<0.10,{ }^{* *} p<0.05,{ }^{* * *} p<.01$ 
Table 5: Second-Step 2SLS Regression Results

(Dependent variable: $\Theta_{j}+\beta_{h} \ln p_{j}$, housing price adjusted mean utilities from city $j$ )

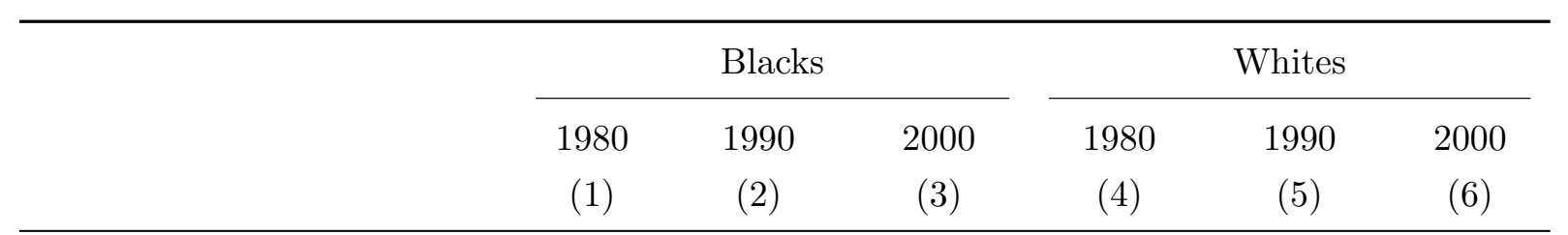

IV: Fiscal instruments

Panel A. Baseline: all cities

\begin{tabular}{lcccccc}
$\ln ($ Dissimilarity index) & -0.444 & $-2.109^{* * *}$ & $-1.903^{* * *}$ & $-3.763^{* * *}$ & $-2.923^{* * *}$ & $-1.690^{* * *}$ \\
& $(0.575)$ & $(0.405)$ & $(0.360)$ & $(0.746)$ & $(0.494)$ & $(0.378)$ \\
& & & & & & \\
$p$-value of Hansen's J & 0.000 & 0.066 & 0.826 & 0.407 & 0.326 & 0.107 \\
$F$-statistics & 11.213 & 27.443 & 26.173 & 15.981 & 27.443 & 26.655 \\
$R^{2}$ & 0.812 & 0.746 & 0.782 & 0.597 & 0.610 & 0.688 \\
Observations & 176 & 203 & 184 & 185 & 203 & 185 \\
\hline
\end{tabular}

Panel B. a subset of cities available for both race and all decades

\begin{tabular}{lcccccc}
$\ln$ (Dissimilarity index) & -0.854 & $-2.532^{* * *}$ & $-1.761^{* * *}$ & $-4.469^{* * *}$ & $-3.384^{* * *}$ & $-1.676^{* * *}$ \\
& $(0.665)$ & $(0.493)$ & $(0.375)$ & $(1.084)$ & $(0.655)$ & $(0.399)$ \\
& & & & & & \\
$p$-value of Hansen's J & 0.002 & 0.055 & 0.799 & 0.743 & 0.930 & 0.174 \\
$F$-statistics & 10.662 & 18.410 & 23.367 & 10.662 & 18.410 & 23.367 \\
$R^{2}$ & 0.818 & 0.759 & 0.798 & 0.526 & 0.567 & 0.703 \\
Observations & 161 & 161 & 161 & 161 & 161 & 161 \\
\hline
\end{tabular}

IV: Number of inter- and intra-county rivers

Panel C. Baseline: all cities

\begin{tabular}{lcccccc}
$\ln ($ Dissimilarity index) & -1.735 & $-1.566^{*}$ & -0.997 & $-3.035^{* *}$ & -1.480 & -0.405 \\
& $(1.533)$ & $(0.898)$ & $(1.056)$ & $(1.438)$ & $(0.912)$ & $(1.142)$ \\
& & & & & & \\
$p$-value of Hansen's J & 0.205 & 0.564 & 0.182 & 0.464 & 0.024 & 0.014 \\
$F$-statistics & 3.694 & 5.720 & 2.651 & 4.462 & 5.720 & 2.723 \\
$R^{2}$ & 0.776 & 0.767 & 0.821 & 0.679 & 0.734 & 0.753 \\
Observations & 176 & 203 & 184 & 185 & 203 & 185 \\
\hline
\end{tabular}

Panel D. a subset of cities available for both race and all decades

\begin{tabular}{lcccccc}
$\ln$ (Dissimilarity index) & -1.840 & -1.617 & -0.529 & -2.906 & -1.342 & -0.220 \\
& $(1.770)$ & $(1.032)$ & $(1.205)$ & $(1.809)$ & $(1.100)$ & $(1.368)$ \\
& & & & & & \\
$p$-value of Hansen's J & 0.114 & 0.813 & 0.078 & 0.415 & 0.036 & 0.013 \\
$F$-statistics & 2.927 & 3.676 & 1.844 & 2.927 & 3.676 & 1.844 \\
$R^{2}$ & 0.789 & 0.798 & 0.825 & 0.692 & 0.754 & 0.756 \\
Observations & 161 & 161 & 161 & 161 & 161 & 161 \\
\hline
\end{tabular}

Notes: Although not presented, each regression in each panel here includes a constant and the same set of controls as in panel A of Table 4. p-value of Hansen's J tests the overidentifying restrictions in the presence of heterogeneity. $F$-statistics tests the joint significance of excluded instruments in the first stage under the assumption of heterogeneity. Robust standard errors adjusted for heterogeneity are in parentheses.

${ }^{*} p<0.10,{ }^{* *} p<0.05,{ }^{* * *} p<.01$ 
Table 6: Coefficients of Log Dissimilarity Index from Alternative Specifications

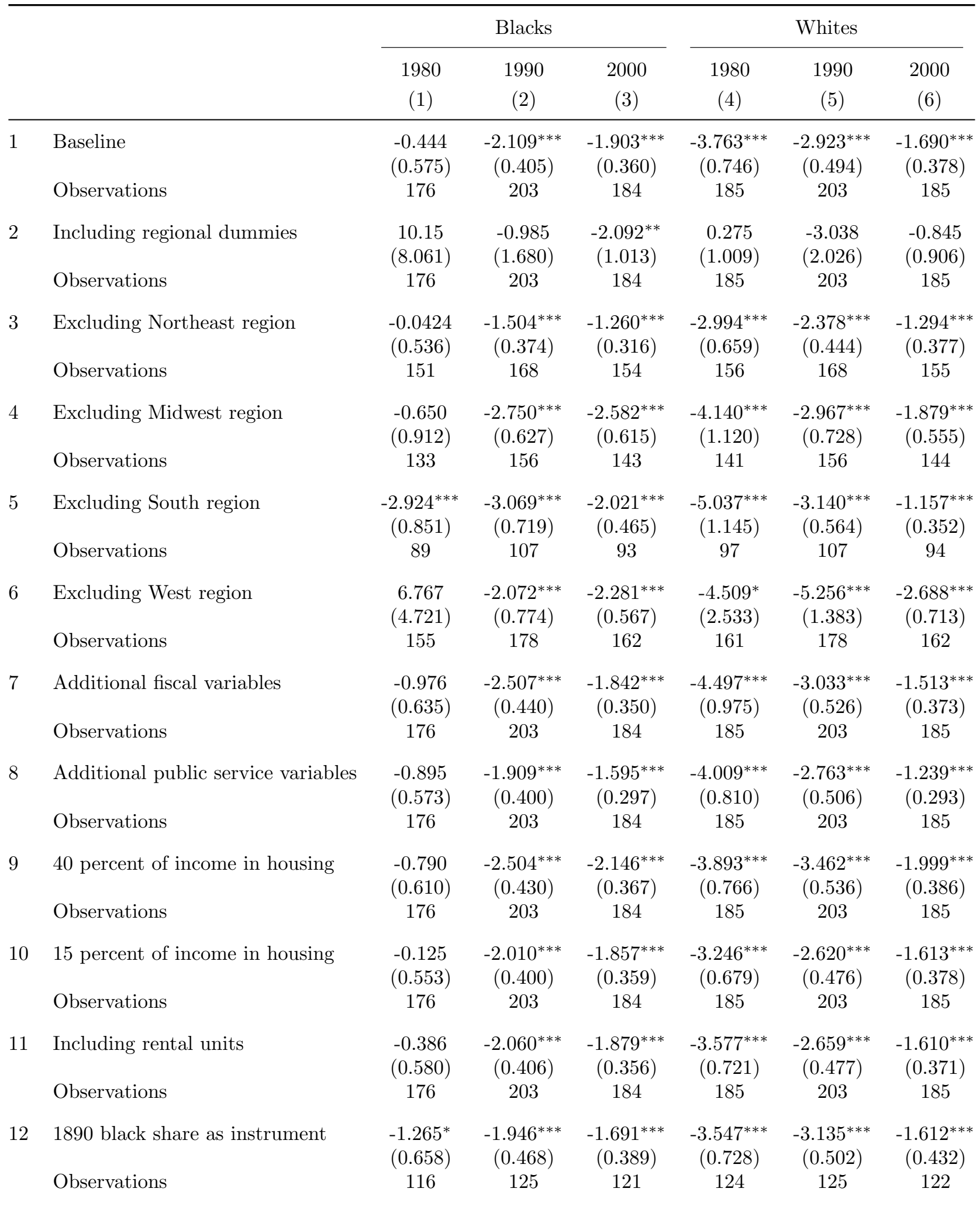

Notes: The first row reproduces the baseline estimates of the mean preferences for segregation presented in panel $\mathrm{A}$ of Table 5. In the corresponding sample, unless otherwise noted in the text, the regression specifications of robust analysis are the same as the baseline specifications. Robust standard errors adjusted for heterogeneity are in parentheses.

${ }^{*} p<0.10,{ }^{* *} p<0.05,{ }^{* * *} p<.01$ 
Table 7: Estimated Marginal Willingness to Pay for Residential Segregation

\begin{tabular}{|c|c|c|c|c|c|c|}
\hline & \multicolumn{3}{|c|}{ Blacks } & \multicolumn{3}{|c|}{ Whites } \\
\hline & $\begin{array}{c}1980 \\
(1) \\
\end{array}$ & $\begin{array}{c}1990 \\
(2) \\
\end{array}$ & $\begin{array}{c}2000 \\
(3) \\
\end{array}$ & $\begin{array}{c}1980 \\
(4)\end{array}$ & $\begin{array}{c}1990 \\
(5) \\
\end{array}$ & $\begin{array}{c}2000 \\
(6) \\
\end{array}$ \\
\hline Mean MWTP (OLS) & 46.285 & 252.253 & 176.260 & 103.712 & 125.221 & 84.165 \\
\hline Mean MWTP (Baseline 2SLS) & 88.579 & 528.829 & 436.180 & 675.206 & 429.601 & 301.352 \\
\hline Age $^{*} \ln S_{j}$ & -18.554 & -29.588 & -4.355 & -5.562 & 1.470 & -1.783 \\
\hline High school or less dummy* $\ln S_{j}$ & 18.155 & 16.048 & -15.128 & 2.871 & -13.962 & -4.101 \\
\hline The presence of children dummy* $\ln S_{j}$ & -3.192 & 5.767 & 31.630 & 22.070 & 31.158 & 46.005 \\
\hline
\end{tabular}

Notes: This table reports the marginal willingness to pay for a one-percentage-point reduction in the dissimilarity index for blacks and whites in 1980, 1990, and 2000. The formula of MWTP is $\frac{\beta_{s}+\sum_{c} z_{i c} \beta_{s c}}{\beta_{w}} \frac{W_{i j}}{S_{j}}$, where $W_{i j}$ and $S_{j}$ are evaluated by using the 1990 median household income $\left(W_{i j}=\$ 35,763\right.$ in 1999 dollars $)$ and the 1990 mean dissimilarity index $\left(S_{j}=0.568\right)$. The first and second rows present mean MWTP by using the baseline OLS and fiscal instrumental variables estimates of mean preferences for segregation (panels A of Tables 4 and 5 ). For the heterogeneous MWTP in the last three rows, $\beta_{w}$ and $\beta_{s c}$ are taken from Table 3. 
Table A1: Descriptive Statistics of Household Heads

\begin{tabular}{lrrrrrrrr}
\hline & \multicolumn{3}{c}{ Blacks } & & \multicolumn{3}{c}{ Whites } \\
\cline { 2 - 3 } & 1980 & 1990 & 2000 & & 1980 & 1990 & 2000 \\
\hline Less than high school & 0.176 & 0.077 & 0.064 & & 0.101 & 0.063 & 0.047 \\
High school & 0.434 & 0.372 & 0.464 & & 0.339 & 0.305 & 0.329 \\
Some college & 0.240 & 0.382 & 0.284 & & 0.234 & 0.309 & 0.234 \\
College or more & 0.150 & 0.169 & 0.188 & & 0.326 & 0.323 & 0.389 \\
Male & 0.632 & 0.542 & 0.459 & & 0.824 & 0.764 & 0.716 \\
Marriage status & 0.740 & 0.602 & 0.503 & & 0.818 & 0.740 & 0.678 \\
Have a child & 0.641 & 0.624 & 0.649 & & 0.562 & 0.517 & 0.488 \\
Income & 26163 & 26183 & 28124 & & 35794 & 39189 & 42321 \\
& $(15059)$ & $(16939)$ & $(22555)$ & & $(20410)$ & $(29340)$ & $(38617)$ \\
\hline
\end{tabular}

Notes: All cell entries are sample means except in the last row the standard deviations of income are also presented in parentheses.

Table A2: Summary of the Estimates of Wage Regressions

\begin{tabular}{|c|c|c|c|c|c|c|}
\hline & \multicolumn{2}{|c|}{1980} & \multicolumn{2}{|c|}{1990} & \multicolumn{2}{|c|}{2000} \\
\hline & Mean & Std. Dev. & Mean & Std. Dev. & Mean & Std. Dev. \\
\hline Constant & 7.670 & 0.366 & 7.505 & 0.481 & 7.724 & 0.260 \\
\hline White & 0.140 & 0.176 & 0.153 & 0.251 & 0.150 & 0.111 \\
\hline High school graduates & 0.230 & 0.097 & 0.255 & 0.132 & 0.251 & 0.073 \\
\hline Some college & 0.338 & 0.122 & 0.438 & 0.141 & 0.437 & 0.089 \\
\hline College degree or more & 0.584 & 0.135 & 0.783 & 0.157 & 0.810 & 0.111 \\
\hline Male & 0.644 & 0.095 & 0.528 & 0.090 & 0.452 & 0.067 \\
\hline Age & 0.065 & 0.015 & 0.071 & 0.018 & 0.066 & 0.011 \\
\hline Age square & -0.0006 & 0.0002 & -0.0007 & 0.0002 & -0.0006 & 0.0001 \\
\hline Marriage status & 0.148 & 0.073 & 0.175 & 0.078 & 0.175 & 0.043 \\
\hline Observations(cities) & \multicolumn{2}{|c|}{258} & \multicolumn{2}{|c|}{281} & \multicolumn{2}{|c|}{288} \\
\hline
\end{tabular}

Notes: This table summarizes the estimates from city-specific wage regressions for 1980, 1990, and 2000. 
Table A3: Descriptive Statistics of Housing Characteristics

\begin{tabular}{|c|c|c|c|c|}
\hline Variables & Data description & 1980 & 1990 & 2000 \\
\hline Rooms2 & 2 rooms in dwelling & 0.002 & 0.008 & 0.011 \\
\hline Rooms3 & 3 rooms in dwelling & 0.014 & 0.032 & 0.040 \\
\hline Rooms4 & 4 rooms in dwelling & 0.079 & 0.103 & 0.085 \\
\hline Rooms5 & 5 rooms in dwelling & 0.230 & 0.220 & 0.206 \\
\hline Rooms6 & 6 rooms in dwelling & 0.284 & 0.245 & 0.232 \\
\hline Rooms7 & 7 rooms in dwelling & 0.189 & 0.176 & 0.175 \\
\hline Rooms8 & 8 rooms in dwelling & 0.114 & 0.114 & 0.128 \\
\hline Rooms9 & 9 rooms in dwelling & 0.088 & 0.104 & 0.124 \\
\hline Bedrooms1 & 1 bedrooms in dwelling & 0.024 & 0.033 & 0.036 \\
\hline Bedrooms2 & 2 bedrooms in dwelling & 0.218 & 0.215 & 0.190 \\
\hline Bedrooms3 & 3 bedrooms in dwelling & 0.531 & 0.516 & 0.503 \\
\hline Bedrooms4 & 4 bedrooms in dwelling & 0.191 & 0.199 & 0.226 \\
\hline Bedrooms5 & $5+$ bedrooms in dwelling & 0.037 & 0.038 & 0.045 \\
\hline Acreprop1- & Acreage of property less than 1 acre & 0.893 & 0.829 & 0.825 \\
\hline Acreprop1-9 & Acreage of property 1-9 acre & 0.107 & 0.136 & 0.152 \\
\hline Acreprop10+ & Acreage of property $10+$ acre & & 0.035 & 0.024 \\
\hline Kitchen & With kitchen in the dwelling & 0.993 & 0.998 & 0.998 \\
\hline Plumbing & With plumbing in the dwelling & 0.996 & 0.997 & 0.997 \\
\hline Year1 & Years of dwelling $0-1$ & 0.030 & 0.023 & 0.030 \\
\hline Year2 & Years of dwelling 2-5 & 0.096 & 0.105 & 0.101 \\
\hline Year3 & Years of dwelling 6-10 & 0.106 & 0.102 & 0.100 \\
\hline Year4 & Years of dwelling 11-20 & 0.214 & 0.244 & 0.196 \\
\hline Year5 & Years of dwelling 21-30 & 0.235 & 0.205 & 0.213 \\
\hline Year6 & Years of dwelling 31-40 & 0.114 & 0.216 & 0.174 \\
\hline Year7 & Years of dwelling $41-50$ & 0.205 & 0.105 & 0.186 \\
\hline Unit1 & Mobile home or trailer & & 0.068 & 0.074 \\
\hline Unit2 & Boat, tent, van, other & & 0.006 & 0.001 \\
\hline Unit3 & 1-family house, detached & 0.946 & 0.819 & 0.806 \\
\hline Unit4 & 1-family house, attached & 0.054 & 0.056 & 0.064 \\
\hline Unit5 & 2-family building & & 0.012 & 0.009 \\
\hline Unit6 & 3-4 family building & & 0.007 & 0.009 \\
\hline Unit7 & 5-9 family building & & 0.008 & 0.009 \\
\hline Unit8 & 10-19 family building & & 0.007 & 0.007 \\
\hline Unit9 & 20-49 family building & & 0.007 & 0.008 \\
\hline Unit10 & $50+$ family building & & 0.011 & 0.013 \\
\hline Observations & & 288938 & 346026 & 1898960 \\
\hline
\end{tabular}

Notes: This table summarizes the characteristics of owner-occupied houses used in baseline housing-price regressions. All cell entries are sample means. Data come from 1980 1\%, $19901 \%$, and 2000 5\% IPUMS. 
Table A4: Estimates of Housing-Price Regressions

\begin{tabular}{|c|c|c|c|c|c|c|}
\hline \multirow[b]{2}{*}{ Rooms3 } & \multicolumn{2}{|c|}{1980} & \multicolumn{2}{|c|}{1990} & \multicolumn{2}{|c|}{2000} \\
\hline & -0.0380 & $(0.0283)$ & $0.127^{* * *}$ & $(0.0167)$ & $0.126^{* * *}$ & $(0.00661)$ \\
\hline Rooms4 & 0.0213 & $(0.0277)$ & $0.153^{* * *}$ & $(0.0176)$ & $0.0891^{* * *}$ & $(0.00695)$ \\
\hline Rooms5 & $0.209^{* * *}$ & $(0.0277)$ & $0.331^{* * *}$ & $(0.0178)$ & $0.242^{* * *}$ & $(0.00696)$ \\
\hline Rooms6 & $0.376^{* * *}$ & $(0.0278)$ & $0.494^{* * *}$ & $(0.0179)$ & $0.383^{* * *}$ & $(0.00699)$ \\
\hline Rooms7 & $0.549^{* * *}$ & $(0.0278)$ & $0.652^{* * *}$ & $(0.0180)$ & $0.520^{* * *}$ & $(0.00703)$ \\
\hline Rooms8 & $0.697^{* * *}$ & $(0.0279)$ & $0.791^{* * *}$ & $(0.0181)$ & $0.647^{* * *}$ & $(0.00708)$ \\
\hline Rooms9 & $0.914^{* * *}$ & $(0.0280)$ & $0.989^{* * *}$ & $(0.0182)$ & $0.852^{* * *}$ & $(0.00714)$ \\
\hline Bedrooms2 & $0.0729^{* * *}$ & $(0.00949)$ & $0.134^{* * *}$ & $(0.00975)$ & $0.144^{* * *}$ & $(0.00404)$ \\
\hline Bedrooms3 & $0.116^{* * *}$ & $(0.00965)$ & $0.168^{* * *}$ & $(0.0103)$ & $0.210^{* * *}$ & $(0.00426)$ \\
\hline Bedrooms4 & $0.116^{* * *}$ & $(0.00995)$ & $0.214^{* * *}$ & $(0.0106)$ & $0.291^{* * *}$ & $(0.00438)$ \\
\hline Bedrooms5 & $0.131^{* * *}$ & $(0.0114)$ & $0.235^{* * *}$ & $(0.0115)$ & $0.382^{* * *}$ & $(0.00484)$ \\
\hline Kitchen & $0.137^{* * *}$ & $(0.0141)$ & $0.201^{* * *}$ & $(0.0297)$ & $0.194^{* * *}$ & $(0.0144)$ \\
\hline Plumbing & $0.783^{* * *}$ & $(0.0251)$ & $0.401^{* * *}$ & $(0.0277)$ & $0.145^{* * *}$ & $(0.0110)$ \\
\hline Acreprop1-9 & $0.161^{* * *}$ & $(0.00322)$ & $0.136^{* * *}$ & $(0.00274)$ & $0.231^{* * *}$ & $(0.00119)$ \\
\hline Acreprop10+ & & & $0.318^{* * *}$ & $(0.00637)$ & $0.458^{* * *}$ & $(0.00346)$ \\
\hline Year1 & $0.681^{* * *}$ & $(0.00511)$ & $0.519^{* * *}$ & $(0.00598)$ & $0.476^{* * *}$ & $(0.00234)$ \\
\hline Year2 & $0.619^{* * *}$ & $(0.00354)$ & $0.472^{* * *}$ & $(0.00392)$ & $0.422^{* * *}$ & $(0.00153)$ \\
\hline Year3 & $0.497^{* * *}$ & $(0.00356)$ & $0.368^{* * *}$ & $(0.00405)$ & $0.331^{* * *}$ & $(0.00151)$ \\
\hline Year4 & $0.418^{* * *}$ & $(0.00309)$ & $0.234^{* * *}$ & $(0.00349)$ & $0.212^{* * *}$ & $(0.00131)$ \\
\hline Year5 & $0.318^{* * *}$ & $(0.00303)$ & $0.150^{* * *}$ & $(0.00348)$ & $0.0678^{* * *}$ & $(0.00126)$ \\
\hline Year6 & $0.164^{* * *}$ & $(0.00379)$ & $0.0991^{* * *}$ & $(0.00339)$ & $0.0263^{* * *}$ & $(0.00128)$ \\
\hline Unit1 & & & $-1.263^{* * *}$ & $(0.00542)$ & $-1.291^{* * *}$ & $(0.00245)$ \\
\hline Unit2 & & & $-0.0550^{* * *}$ & $(0.0136)$ & $-1.200^{* * *}$ & $(0.0273)$ \\
\hline Unit4 & $-0.207^{* * *}$ & $(0.00482)$ & $-0.132^{* * *}$ & $(0.00384)$ & $-0.108^{* * *}$ & $(0.00158)$ \\
\hline Unit5 & & & $0.0929^{* * *}$ & $(0.00937)$ & $0.0743^{* * *}$ & $(0.00463)$ \\
\hline Unit6 & & & -0.00823 & $(0.0115)$ & $-0.0813^{* * *}$ & $(0.00451)$ \\
\hline Unit7 & & & $-0.116^{* * *}$ & $(0.00956)$ & $-0.169^{* * *}$ & $(0.00411)$ \\
\hline Unit8 & & & $-0.128^{* * *}$ & $(0.0110)$ & $-0.177^{* * *}$ & $(0.00504)$ \\
\hline Unit9 & & & $-0.109^{* * *}$ & $(0.0119)$ & $-0.102^{* * *}$ & $(0.00571)$ \\
\hline Unit10 & & & $0.0898^{* * *}$ & $(0.0126)$ & $0.104^{* * *}$ & $(0.00527)$ \\
\hline$R^{2}$ & 0.998 & & 0.998 & & 0.998 & \\
\hline Observations & 288938 & & 346026 & & 1898960 & \\
\hline
\end{tabular}

Notes: Data come from 1980 1\%, 1990 1\%, and 2000 5\% IPUMS. Robust standard errors adjusted for heterogeneity are in parentheses.

${ }^{*} p<0.10,{ }^{* *} p<0.05,{ }^{* * *} p<.01$ 